NBER WORKING PAPER SERIES

\title{
BEHAVIORAL ECONOMICS PERSPECTIVES ON PUBLIC SECTOR PENSION PLANS
}

\author{
John Beshears \\ James J. Choi \\ David Laibson \\ Brigitte C. Madrian \\ Working Paper 16728 \\ http://www.nber.org/papers/w16728 \\ NATIONAL BUREAU OF ECONOMIC RESEARCH \\ 1050 Massachusetts Avenue \\ Cambridge, MA 02138 \\ January 2011
}

We thank Gwen Reynolds, Janelle Schlossberger, Jessica Zeng, Arash Alidoust, and John Klopfer for their help in going through state, county and city pension documents, calling many public pension offices, and compiling and analyzing the resulting data. Karl Scholz and the other participants in the NBER State and Local Pensions Conference provided many helpful comments. Financial support from the National Institute on Aging (grants R01-AG021650 and P01-AG005842) is gratefully acknowledged. The opinions and conclusions expressed are solely those of the authors. The views expressed herein are those of the authors and do not necessarily reflect the views of the National Bureau of Economic Research.

NBER working papers are circulated for discussion and comment purposes. They have not been peerreviewed or been subject to the review by the NBER Board of Directors that accompanies official NBER publications.

(C) 2011 by John Beshears, James J. Choi, David Laibson, and Brigitte C. Madrian. All rights reserved. Short sections of text, not to exceed two paragraphs, may be quoted without explicit permission provided that full credit, including $(\odot)$ notice, is given to the source. 
Behavioral Economics Perspectives on Public Sector Pension Plans

John Beshears, James J. Choi, David Laibson, and Brigitte C. Madrian

NBER Working Paper No. 16728

January 2011

JEL No. G23,G28,H76

\begin{abstract}
$\underline{\text { ABSTRACT }}$
We describe the pension plan features of the states and the largest cities and counties in the U.S. Unlike in the private sector, defined benefit (DB) pensions are still the norm in the public sector. However, a few jurisdictions have shifted towards defined contribution (DC) plans as their primary savings plan, and fiscal pressures are likely to generate more movement in this direction. Holding fixed a public employee's work and salary history, we show that DB retirement income replacement ratios vary greatly across jurisdictions. This creates large variation in workers' need to save for retirement in other accounts. There is also substantial heterogeneity across jurisdictions in the savings generated in primary DC plans because of differences in the level of mandatory employer and employee contributions. One notable difference between public and private sector DC plans is that public sector primary DC plans are characterized by required employee or employer contributions (or both), whereas private sector plans largely feature voluntary employee contributions that are supplemented by an employer match. We conclude by applying lessons from savings behavior in private sector savings plans to the design of public sector plans.
\end{abstract}

\author{
John Beshears \\ Graduate School of Business \\ Stanford University \\ 518 Memorial Way \\ Stanford, CA 94305-5015 \\ and NBER \\ beshears@stanford.edu \\ James J. Choi \\ Yale School of Management \\ 135 Prospect Street \\ P.O. Box 208200 \\ New Haven, CT 06520-8200 \\ and NBER \\ james.choi@yale.edu
}

\author{
David Laibson \\ Department of Economics \\ Littauer M-12 \\ Harvard University \\ Cambridge, MA 02138 \\ and NBER \\ dlaibson@harvard.edu \\ Brigitte C. Madrian \\ John F. Kennedy School of Government \\ Harvard University \\ 79 JFK Street \\ Cambridge, MA 02138 \\ and NBER \\ Brigitte_Madrian@Harvard.edu
}


Over the past 30 years, employer-sponsored defined contribution (DC) savings plans have displaced defined benefit (DB) pensions in the private sector. There were 2.4 active DB participants for each active DC participant in the private sector in 1975, but these proportions had more than flipped by 2007, when there were 3.4 active DC participants for each active DB participant (U.S. Department of Labor, Employee Benefit Security Administration, 2008 and 2010). Several factors have been implicated in this shift, including increased regulatory costs for DB providers following the passage of the Employee Retirement Income Security Act (ERISA) in 1974, the legislated creation of an attractive (to employers) alternative to the DB pension through section 401(k) of the Internal Revenue Code in 1978, and workers' interest in portable pension benefits as the labor force has become more mobile.

The picture in the public sector is very different. In most jurisdictions, a DB pension is still the primary retirement income benefit offered to employees. However, some jurisdictions have followed the private sector and shifted towards a DC system. Going forward, fiscal pressures are likely to generate more movement in this direction. Even jurisdictions with a primary DB plan currently offer supplemental DC plans.

The distinction between DB and DC plans is an important one. In a DB plan, participants have little impact on the income that they will receive in retirement other than through their choice of when to leave their job. Plan sponsors dictate the formula that determines the payments to retired participants. Sponsors also decide with the help of highly trained financial professionals how much money to save today to fund these future payments and where these savings are invested.

In a DC plan, participants usually must choose how much to spend out of their assets during retirement, how much to contribute to the plan before retirement, and how to invest plan assets with limited guidance from their employer or plan sponsor. The consequences of having individuals with low levels of financial sophistication make complicated financial decisions has been well-documented in the literature: individuals procrastinate, their savings outcomes are heavily influenced by plan design features such as employer-selected defaults, they place too much weight on information that is not relevant (e.g., past asset returns), and they place too little weight on information that is relevant (e.g., mutual fund fees). 
We begin this paper by surveying the retirement plans offered in the public sector, evaluating the generosity of the DB plans and describing the types of DC plans that are available. We find that public sector DB plans generally provide high income replacement rates during retirement for employees who retire from the public sector with long tenures, but even within this set of employees, there is a large amount of heterogeneity in the replacement rate across plans. In contrast, employees who leave the public sector with shorter tenures are not covered as generously. In public DC plans, mandatory employee contributions and employer contributions that are not contingent on employee choices are much more common than in private DC plans, and these combined contributions are often a large fraction of employee salary. We conclude by summarizing previous research findings on employee savings behavior in private DC plans and discussing how this research points to areas where the design of public sector pension plans could be improved.

\section{The Public Sector Pension Landscape}

\section{A. Defined Benefit and Defined Contribution Plans in the Public Sector}

In the United States, there are over 2,500 different public employee retirement systems providing benefits to the over 20 million individuals employed in the public sector. ${ }^{1}$ For most of these employees, the primary retirement income benefit is a DB pension plan. According to Snell (2010a), "91 percent of full-time state and local government employees are covered by a traditional, defined benefit retirement plan." Although DC plans are making some inroads in the public sector, quantifying their importance is difficult because the data collected on public sector retirement plans have largely focused on DB plans.

Pensions \& Investments has compiled data on the 1,000 largest retirement plan sponsors (public and private) in the U.S., as measured by assets under management (Pensions \& Investments, 2010a and 2010b). Of the 1,000 largest plans in 2009, 222 are classified as public

\footnotetext{
${ }^{1}$ The number of retirement systems comes from the U.S. Census Bureau: http://www.census.gov/govs/retire/2008ret05a.html (accessed August 4, 2010). The total number of retirement systems is comprised of 218 state systems, 160 county systems, 2,054 municipal/township systems, and 118 school and special district systems. The number of public sector employees comes from the U.S. Bureau of Labor Statistics: http://www.bls.gov/cps/cpsaat15.pdf (accessed August 5, 2010).
} 
plans. $^{2}$ Among these public plans, DB plans predominate: only $6 \%$ of total assets under management are in DC plans. But 94 of the 222 largest public pension plan sponsors have a DC component, and 38 of these plans have over $\$ 1$ billion in DC assets. ${ }^{3}$

To get a more complete picture of the role of DC plans in the public sector, we compiled information on the retirement plans offered to new hires in 2010 in all 50 states, the District of Columbia, the 20 largest cities, and the 20 largest counties in the U.S. (as measured by population). ${ }^{4}$ Some jurisdictions have a single plan for most or all public sector employees, whereas others have separate plans for different employee categories, such as teachers, public safety workers, and elected officials. ${ }^{5}$ In Tables 1A (states plus Washington D.C.) and 1B (counties and cities), we list the plans available to a general public sector employee. Some plans appear in Table 1 multiple times; for example, a plan that covers workers employed by all levels of government within a state that contains a top-20 city and a top-20 county would show up three times as a plan covering state, county, and city employees.

Tables $1 \mathrm{~A}$ and $1 \mathrm{~B}$ show that DB plans are the predominant primary ${ }^{6}$ retirement plan at all levels of state and local government. But eleven states and Washington D.C. have some sort of DC component in their primary retirement plan, either a DC only plan, a hybrid DB/DC plan (which combines a DB component with a DC component that is distinct from the state's supplemental DC plans), or a plan that allows employees to choose a DC or a hybrid DB/DC plan instead of a DB plan. These DC and hybrid DB/DC offerings are largely recent with all but one being incorporated in the past 15 years. ${ }^{7}$ Fewer large cities and counties have a primary plan with a DC component: only seven of the 40 jurisdictions in Table $1 \mathrm{~B}$.

Regardless of the nature of their primary retirement plan, all of the jurisdictions in Tables 1A and 1B have an optional supplemental DC plan available to employees, and a non-trivial

\footnotetext{
${ }^{2}$ Pensions \& Investments classifies plans as being corporate, public, union, or miscellaneous. A handful of plans classified as "miscellaneous" appear to be public plans (e.g., the Federal Retirement Thrift plan and the Illinois State Universities plan). In the numbers reported here, we follow the Pensions \& Investments categorization.

${ }^{3}$ By comparison, private sector companies like Apple and 7-Eleven have roughly \$1 billion in DC assets under management and no DB assets.

${ }^{4}$ For more information on the legislative history of state defined contribution savings plans, see Snell (2010b).

${ }^{5}$ The determinants of the plan types offered to different groups of public employees is a potential area for future research. For example, do DC plans tend to be offered to employees who are best equipped to make good choices in them?

${ }^{6}$ We define a primary plan as one that is not optional, and a supplemental plans as one in which participation is voluntary.

${ }^{7}$ Washington D.C. made the switch to its defined contribution plan in 1987.
} 
fraction have multiple supplemental options. The need for these supplemental DC plans depends on how well the primary plan is meeting employees' retirement income needs.

\section{B. The Adequacy of State Defined Benefit Pensions}

Public sector DB pensions are often perceived by the public as being quite generous. To see how accurate this perception is, we calculate the extent to which employment automatically generates an annuity stream of income for a stylized public sector employee, ${ }^{8}$ Joe the Bachelor, in each state, assuming Joe retires on January 1, 2010. The metric we use is Joe's replacement rate after taxes and retirement plan contributions: (after-tax automatic retirement annuity income in first retirement year $) \div$ (after-tax salary in final work year - mandatory retirement plan contributions in final work year). We include state DB plan payments (or payments from the DB component of a state hybrid plan) and Social Security payments in Joe's automatic annuity income. Even though Joe is retiring on January 1, 2010, we assume that he worked his entire career under the pension rules being offered to new hires in 2010.

Befitting his name, Joe has never married and has no dependents. The absence of spousal labor and pension income means that the automatic replacement rate we calculate for Joe approximates the ratio of his retirement consumption to his pre-retirement consumption if he does no saving outside the DB pension both before and after retirement. Of course, the beforetax generosity of Joe's state pension benefits does not depend upon his marital status or number of dependents, at least as long as he is alive.

We assume that Joe has a final pre-retirement salary of either $\$ 50,000$ or $\$ 100,000$, and has experienced $1 \%$ annual real wage growth up until age 60 and $0 \%$ nominal wage growth until his retirement at age 65 . We consider six different work histories for Joe:
A) Joe retires having worked for 40 years, all of it in the public sector
B) Joe retires having worked for 35 years, all of it in the public sector
C) Joe retires having worked for 35 years, the first 5 in the private sector and the last 30 in the public sector

\footnotetext{
${ }^{8}$ The analysis that follows assumes that Joe the bachelor is a general state employee. We have done the calculations in Appendix Table B1 assuming that Joe is a K-12 teacher in state, and the qualitative results are very similar (see Appendix B). Note that in some states, the same pension plan covers both general public employees and K-12 teachers, whereas in other states these two groups of employees are covered by separate plans.
} 
D) Joe retires having worked for 35 years, the first 30 in the private sector and the last 5 in the public sector

E) Joe retires having worked for 35 years, the first 15 in the private sector and the last 20 in the public sector

F) Joe retires having worked for 35 years, the first 20 in the public sector and the last 15 in the private sector

Note that in every scenario, the replacement rate Joe would get later in retirement could be different than our calculations here due to cost-of-living adjustments (COLAs). Appendix A (available online) includes more details on the assumptions and methodology we use to calculate Joe's automatic replacement rate, the values of the automatic replacement rate we calculate for Joe in each state, each state's tax treatment of labor income and pension income, and whether each state's employees participate in Social Security.

Table 2 shows summary statistics of the automatic replacement rates, broken out by Joe's final salary, work history, and the type of plan offered by the state. A state that offers employees a choice of plans appears in multiple plan categories - once in each category it offers.

Under most of the scenarios we consider where Joe's final income is $\$ 50,000$, the average automatic replacement rate in plans with at least some DB component is close to or exceeds the 70 to $75 \%$ replacement rate that is often considered adequate. As a point of comparison, Munnell and Soto (2005) calculate that the median U.S. single individual who retired with an employer-sponsored pension between 1999 and 2003 receives Social Security plus pension annuity income (assuming all DC assets are annuitized) equal to $56 \%$ of his average income in the highest five out of the last ten years prior to retirement. ${ }^{9}$ Nonetheless, a need for additional savings remains - even for many public sector employees covered by a DB plan — for several reasons.

First, because the Social Security system is progressive, Joe's average replacement rate is decreasing in his final salary. ${ }^{10}$ For example, when Joe has a 35 year career entirely spent in the public sector, his replacement rate in DB-only plans is 10 percentage points lower on average with a $\$ 100,000$ final income than with a $\$ 50,000$ final income.

\footnotetext{
${ }^{9}$ This comparison shows that public sector compensation appears to be more back-loaded than private sector compensation. It does not show that public sector compensation is more generous than private sector compensation. ${ }^{10}$ The only time Joe's replacement rate is not affected by his final salary is in states with DC-only plans whose employees do not participate in Social Security. The replacement rate in these states is $0 \%$ regardless of Joe's income.
} 
Second, in the DB-only plans and the hybrid DB/DC plans, Joe's automatic replacement rate falls if he has spent less time working in the public sector. This is because the typical DB pension formula increases benefits with years of service. ${ }^{11}$ If Joe's last job is in the public sector with a final income of $\$ 50,000$, his average replacement rate in a DB-only plan decreases by 8 percentage points as his years of public sector work decrease from 40 to 35, by another 8 percentage points as his tenure decreases from 35 to 30, and by another 17 percentage points as his tenure decreases from 30 to 20 . If Joe works only five years in the public sector, there are many states whose DB systems do not give Joe any automatic annuity because he does not satisfy the plan vesting requirements. Thus, Joe's automatic annuity income would come solely from Social Security. In most of these states, Joe would receive a refund of his contributions to the state pension system if the system requires employee contributions. ${ }^{12}$

Third, conditional on working partly in the public sector and partly in the private sector, Joe has a lower replacement rate if he ends his career in the private sector than if he ends his career in the public sector. This is because the DB pension formulas are a function of Joe's nominal final average salary in the public sector. For example, if Joe retires with a final average salary of $\$ 50,000$ and works 20 years in the public sector and 15 years in the private sector, his average DB-only replacement rate is 20 percentage points higher if he retires from the public sector than if he retires from the private sector (96\% versus $76 \%)$.

Fourth, even holding fixed Joe's final income and work history, there is substantial heterogeneity in his automatic replacement rate across states. For example, with a final average salary of $\$ 50,000$ and a 35-year career spent entirely in the public sector, the average replacement rate across all DB-only plans is $121 \%$. If Joe worked in Pennsylvania, his replacement rate would be a much higher $150 \%$. But if Joe worked in Maine, his replacement rate would be only $79 \%$. Joe's average automatic replacement rate in states with hybrid DB/DC plans is lower on average than in the states with DB-only plans - $90 \%$ versus $121 \%$ - as would be expected, since it is intended that Joe fund some of his retirement with assets in the DC component of these plans. There is also substantial variation in Joe's automatic replacement rate

\footnotetext{
${ }^{11}$ In some states, the DB replacement rate is capped, so additional years of service do not increase pension benefits after some point.

${ }^{12}$ In most states with DB plans, if Joe leaves public sector employment before he is vested, only his contributions are refunded. He does not receive any investment return on his contributions nor any of the employer contributions made on his behalf.
} 
within the small number of hybrid DB/DC plans, ranging from a low of $44 \%$ in Ohio to a high of $118 \%$ in Oregon. In DC-only plans, Joe's replacement rate is either 0\% (in states whose newly hired employees do not participate in Social Security ${ }^{13}$ ) or around 50\% (the replacement rate that he gets from Social Security alone after taxes).

The automatic replacement rates in Table 2 are derived assuming that Joe accumulates benefits for his entire career under the rules in place for employees newly hired today. How has this automatic replacement rate changed over time? Figure 1 plots one measure of this change for Joe if he works his entire 35-year career in the public sector (work history B above) and has a $\$ 50,000$ final salary. The vertical axis is the highest automatic replacement rate Joe could get in his state if he spent his entire career under the rules for today's new hires. The horizontal axis is the most generous automatic replacement rate Joe could get if he spent his career under the rules actually experienced by employees who started working in 1975 and retired at the beginning of 2010.

Most states are fairly close to the 45-degree line, indicating that the automatic replacement rate has not changed much over time, at least for employees who spend their entire careers in the public sector. The few substantial changes have mostly lowered the automatic replacement rate; conditional upon changing, the average change is a 10 percentage point decrease.

Several states have decreased the generosity of their DB pension in ways that do not show up in Figure 1. For example, an increase in the years of service at which employees vest would reduce the automatic replacement ratio of employees who leave the public sector with years of service between the old and the new vesting thresholds. Many states have adopted "antispiking provisions" to combat the practice of artificially inflating pay in the final year or two before retirement by taking extremely high amounts of overtime or getting short-term "promotions" into higher-paying positions. Since pension formulas depend on some measure of final average pay, spiking increases pension payouts in retirement. ${ }^{14}$ We have assumed that Joe's pay is flat during his last five years before retirement, so the automatic replacement rates that we

\footnotetext{
${ }^{13}$ Newly hired state employees in Alaska, Colorado, Louisiana, Maine, Massachusetts, Nevada and Ohio do not make Social Security contributions, and their employer does not either. Consequently, their public sector earnings history is not counted in determining their Social Security benefits.

${ }^{14}$ In practice, anti-spiking provisions cap the annual salary growth that is used to calculate a worker's pension benefit.
} 
calculate are not influenced by spiking. States are also reducing the generosity of their retiree health insurance, a valuable benefit that we do not incorporate into our replacement rate calculation. The current fiscal situation facing many jurisdictions will likely precipitate many more such changes. To the extent that pensions are becoming less generous in some of the less visible ways discussed above, this may increase the need for supplemental DC savings.

\section{The Adequacy of State Defined Contribution Pensions}

The adequacy of DC savings plans is more difficult to assess than that of DB plans because their adequacy often depends significantly on participant behavior: Are employees participating, how much are they contributing, and what type of asset allocation do they choose? In most private sector 401(k) plans, there are many ways employees can fall short (Munnell and Sundén, 2004): they can delay enrolling in the plan, choose a contribution rate that is too low to generate the necessary resources to maintain consumption in retirement, or choose an inappropriate asset allocation (e.g., investing heavily in employer stock, investing in high-fee funds, or investing in a manner that does not match their risk tolerance).

Table 3 lists some characteristics of states' primary DC plans. Optional supplementary DC plans and the DC component of hybrid DB/DC plans are not included in the table. In contrast to most private sector DC plans, plan contributions are mandatory for most state employees whose primary plan is the DC plan. ${ }^{15}$ Thus, in the three states whose only primary plan is the DC plan, contributions to the DC plan are automatic and employees cannot opt out. In the states that allow employees to choose a DC plan as their primary plan, the default primary plan is the DB plan (or the hybrid DB/DC plan in the State of Washington), so mandatory DC plan contributions do not commence unless the employee actively enrolls in the DC plan.

In the private sector, most DC plans are funded by elective employee contributions and an employer contribution that depends on the employee's contribution (e.g., the employer will match $50 \%$ of employee contributions up to $3 \%$ of pay). The contribution rules in state DC plans are usually very different. Only Michigan allows variable employee contributions that are matched by the employer, as is the norm in the private sector. Instead, state DC plans usually offer an employer contribution that is not contingent on employee contributions, ranging from

\footnotetext{
${ }^{15}$ States often exempt some groups of employees from retirement plan participation, but these employee groups tend to be a small (e.g., temporary or part-time workers).
} 
4\% of salary in Michigan to $10.15 \%$ of salary in Colorado. Most also fix the employee contribution at a level between $4 \%$ and $10 \%$ of salary, although two jurisdictions (Washington DC and Florida) do not allow employee contributions at all.

One area where public and private sector DC plans are similar is the investment options offered. The number of investment options ranges from 10 to the low 20 s with only one exception, South Carolina, which has four different investment fund managers and a total of 85 funds. All of the fund menus have investment options that span the risk-expected return spectrum, and most include target date funds. The default fund is either an age-appropriate target date fund or a balanced fund with the exception of Michigan, where the default is a fixed income fund. This is in line with the private sector, which has also moved toward target date and balanced fund defaults that satisfy the Qualified Default Investment Alternative (QDIA) guidelines of the Pension Protection Act of 2006.

Employees' own contributions are always immediately vested in state DC plans. The vesting of employer contributions varies across jurisdictions, from immediate vesting in South Carolina to cliff vesting after 5 years in Montana. Employees in most states become incrementally vested in their employer contributions over time, until they are fully vested after 4 or 5 years. The range of state vesting schedules mirrors what we observe in private sector plans.

Participants in state DC plans are less likely than participants in private sector DC plans to end up with extremely low retirement savings, since most states impose high minimum contribution rates. Colorado and Ohio require combined employer plus employee contribution rates in excess of $18 \%$. Four other states mandate combined contribution rates greater than or equal to $10 \%$. But some states have rather low mandatory combined contribution rates. Washington D.C. contributes only 5\% of salary and allows no employee contributions, and North Dakota's combined mandatory contribution is $8.12 \%$ of salary, with no possibility for employees to contribute more. Michigan's minimum mandatory contribution rate is $4 \%$, but employees can accumulate more by making additional optional employee contributions and earning the accompanying employer match. 


\section{Behavioral Economics and Retirement Savings}

We now turn to a brief summary of the behavioral economics literature on retirement savings. In Section III, we will apply these research findings to the public sector retirement plans that we have described in Section I.

Several recent papers document a pervasive lack of financial literacy in the U.S. population (e.g., Lusardi and Mitchell, 2006 and 2007; Lusardi, Mitchell and Curto, 2010; Lusardi and Tufano, 2009; Applied Research and Consulting, 2009). This low level of financial literacy carries over to the specific domain of employer-sponsored retirement plans. Gustman, Steinmeier, and Tabatabai (2007) and Chan and Stevens (2008) show that many Health and Retirement Survey respondents do not understand important features of their retirement plan, including whether the plan is a DB or a DC plan, the age at which they qualify for full benefits, and the relationship between continued work and future benefits. Choi, Laibson, and Madrian (forthcoming) similarly show that many employees in one DC savings plan do not know their employer match. Finally, Brown and Weisbenner (2009) document that individuals participating in the State Universities Retirement System of Illinois are confused about which plan option best meets their needs.

Complicated financial decisions can be overwhelming for many individuals, especially those with little financial expertise and experience. Saving and investing for retirement can be especially daunting, as it involves making large long-term commitments in a domain in which many individuals will never develop significant expertise. Learning is hindered by the fact that each individual goes through the lifecycle savings problem only once, outcomes are realized with substantial delay and noise, and the rapid pace of financial innovation renders previously acquired knowledge obsolete.

The consequences for savings plan outcomes have been well documented. Several broad patterns of behavior emerge from the literature. First, individuals procrastinate when faced with complicated choices. In the context of retirement saving, this often implies not saving at all. Carroll et al. (2009) document substantial procrastination in 401(k) savings plan enrollment in a large private sector savings plan, even though the costs of delay can be substantial (Choi, Laibson and Madrian, forthcoming). Conversely, Choi, Laibson and Madrian (2009a) and 
Beshears, Choi, Laibson and Madrian (2010a) show that simplifying the savings plan enrollment process leads to sizeable increases in participation.

Second, savings and investment outcomes are heavily influenced by plan design features that matter little in standard economic models. The best evidence on this front is the sensitivity of outcomes to the plan defaults. Savings plan participation increases greatly following employer adoption of automatic enrollment, which changes the plan default from non-participation to participation, and contribution rates and asset allocations shift toward the automatic enrollment defaults (Madrian and Shea, 2001; Choi, Laibson, Madrian and Metrick, 2004 and 2006; Beshears, Choi, Laibson and Madrian, 2008). Allowing employees to choose automatic future contribution rates increases leads to sizeable future increases in savings (Thaler and Benartzi, 2004). Portfolios are more heavily invested in employer stock when the employer match is invested by default in employer stock (Benartzi, 2001; Choi, Laibson and Madrian, 2009b). The fraction of pension beneficiaries choosing a joint and survivor annuity increased substantially when this option became the legal default for married individuals (Holden and Nicholson, 1998; Saku, 2005).

Defaults are not the only plan design feature that significantly influences savings and investment outcomes. In plans without an employer match, discretionary employee contribution rates are influenced by whether mandatory contributions are labeled as employee or employer contributions (Card and Ransom, forthcoming). Several authors have found that asset allocation choices are sensitive to the structure of the investment menu (Benartzi and Thaler, 2001; Brown, Liang, and Weisbenner, 2007; Karlsson, Massa, and Simonov, 2007) and the form on which individuals must indicate their choices (Benartzi and Thaler, 2007).

Third, individuals pay too much attention to irrelevant information and too little attention to relevant information. For example, individuals chase past returns in both their asset allocation choices (Benartzi, 2001; Choi, Laibson, Madrian and Metrick, 2004; Calvet, Campbell, and Sodini, 2009; Choi, Laibson, and Madrian, 2010) and contribution rate choices (Choi, Laibson, Madrian and Metrick, 2009) while paying too little attention to mutual fund fees (Choi, Laibson, and Madrian, 2010).

A fourth pattern is a reliance on heuristics and rules of thumb in decision making. For example, Benartzi and Thaler (2001) document what they call "naïve diversification": 
individuals diversify by investing in several different mutual funds, but they fail to account for the underlying correlations in returns across the funds when making their choices. ${ }^{16}$ Choi, Laibson, Madrian and Metrick (2006) show that employees disproportionately choose 401(k) contribution rates that are divisible by 5 .

Finally, individuals do a poor job of integrating various aspects of their financial lives; rather, they appear to engage in mental accounting, making decisions in each subset of their portfolio without considering their choices in other subsets (Choi, Laibson, and Madrian, 2009b; Card and Ransom, forthcoming).

This long list of biases has complex implications for the overall adequacy of retirement savings. Depending on the institutional environment, some behavioral biases will generate excessive accumulation of retirement wealth whereas other biases will generate inadequate accumulation of retirement wealth.

To illustrate the case of excess accumulation, consider an individual who has a large DB pension claim, but fails to fully account for that claim when making retirement savings decisions. For example, the individual might mentally segregate their DB claim and follow a simple heuristic in choosing an active savings rate in his DC account, for instance, save up to the match threshold, which is $6 \%$ of income in a typical private sector DC plan. Assuming that the employee's contributions are partially matched, the total implicit saving rate could far exceed $20 \%$ once the DB accumulation and Social Security are also taken into account. In this scenario, the individual might save far too much, particularly if he has a low level of labor income and a correspondingly high Social Security replacement rate. Likewise, consider a completely passive individual who works for an employer with a DB plan and also a DC plan that has automatic enrollment, an employer match, and automatic contribution escalation. In this setting, such a household might also end up saving far too much.

On the other hand, the passive behavior noted above could lead to insufficient retirement wealth accumulation in other contexts. For example, a largely passive individual who works for an employer with neither a DB nor a DC savings plan could save far too little.

Behavioral biases therefore predict a mixed picture of heterogeneous savings outcomes, with this heterogeneity driven by the interaction between behavioral biases (like passivity or

\footnotetext{
${ }^{16}$ However, see the critique of this result by Huberman and Jiang (2006)
} 
mental accounting) and the individual's institutional environment. Researchers who study savings adequacy have reached differing conclusions about the extent to which individuals are financially prepared for retirement. Some argue that individuals are largely well-positioned (e.g. Sholz, Seshadri and Khitatrakun, 2006; Engen, Gale and Uccello, 1999), while others conclude that most individuals are falling short of where they need to be (Munnell, Webb and Golub-Sass, 2007).

\section{Implications for Public Sector Retirement Plans}

What are the implications of these behavioral patterns for thinking about how well public sector retirement plans meet the retirement income needs of public sector employees?

We start by considering the situation of employees who have a primary DB plan. DB plans have been characterized as being less complicated than DC plans for their participants. Indeed, DC plans demand - or at least allow - a substantial amount of individual autonomy, whereas DB plans require almost no choices by participants before retirement. But there are many complicated features of DB plans that have implications for how employees use the supplemental DC savings plans they are offered.

The formulas determining DB pension payouts seem relatively straightforward on the surface: final average salary multiplied by years of service multiplied by a retirement factor. But these formulas often have complicated wrinkles, such as limits on the growth in final wages that will count in the formula, future cost-of-living adjustments that are hard to value, and rules about the combination of age and years of service that must be attained to receive a full benefit. Many individuals have misconceptions about their retirement benefits, which may affect their choices about how much to save in their supplemental DC plans.

DB plans reward tenure, since most payout formulas depend directly on years of service and some measure of final average pay, which is itself often related to tenure. Individuals who leave the public sector with relatively low levels of tenure will be entitled to very little or nothing at all. Although the common perception is that public sector workers are generally long-term employees, a recent Maine task force report claims that over half of public sector workers in Maine leave the public sector before reaching the 5 years of service necessary to vest (Maine 
URP Task Force, 2010). If this is true in other states as well, then more attention probably needs to be paid to supplemental DC plans in the public sector.

Finally, the Windfall Elimination Provision (WEP) greatly complicates estimating the level of Social Security income that employees of six states (Colorado, Louisiana, Maine, Massachusetts, Nevada, and Ohio) will receive. While employed by these states, employees make no contributions to Social Security, and neither does their employer. Consequently, earnings from employment in these states are not counted towards determining Social Security benefits. But some employees have long enough careers to qualify for Social Security benefits in addition to their state pension. The WEP reduces Social Security payments to these employees. As explained on the Social Security web site:

"Before 1983, people who worked mainly in a job not covered by Social Security had their Social Security benefits calculated as if they were long-term, low-wage workers. They had the advantage of receiving a Social Security benefit representing a higher percentage of their earnings, plus a pension from a job where they did not pay Social Security taxes. Congress passed the Windfall Elimination Provision to remove that advantage."

(Source: http://www.ssa.gov/pubs/10045.html, accessed August 7, 2010.)

The annual statements that Social Security sends to participants projecting their future benefits do not account for the effects of the WEP, so affected state employees may mistakenly believe that they are entitled to higher Social Security benefits than they will in fact receive, altering their savings and retirement decisions.

In some states, employees have a choice of plans in which to participate, which adds yet another layer of complexity. Employees do not typically have the option of procrastinating indefinitely, because there is a deadline by which a decision must be made. ${ }^{17}$ But in fact, the decision does not need to be explicitly made, since the employer specifies a default plan for individuals who do not state a preference. Table 4 lists the states that offer a choice of primary plan, which plan is their default option, and the fraction of new employees who end up in each option in the states from which were able to get that information. The default is the DB plan in all of the choice states except Washington, where the default is a hybrid DB/DC plan. Consistent with previous research, the large majority of employees-79\% to $87 \%$ - end up in whichever plan is the default.

\footnotetext{
${ }^{17}$ For the states with a plan choice in Table 1A, employees have between 30 days and twelve months to opt out of
} the default plan. 
Beshears, Choi, Laibson and Madrian (2008) discuss several reasons why defaults are powerful. One may be particularly relevant here: the perception that the default is the employerendorsed option. Most workers probably lack the knowledge necessary to map each retirement plan to their preferences, so the default may be particularly likely to be perceived as the correct course of action. Yang (2005), Brown and Weisbenner (2009), and Goda and Manchester (2010) all document strong default effects among employees who have a choice between a DB and a DC plan (the employees studied by Brown and Weisbenner had a choice among three different plans). In the organization studied by Goda and Manchester, the default differed by age: employees older than 45 had a DB plan default, while employees younger than 45 had a DC plan default. Employees who are just above the age- 45 cutoff are 60 percentage points more likely to be in the DB plan than employees who are just below the age-45 cutoff. Goda and Manchester's analysis suggests that following the age-based default rule was close to optimal ex ante for employees. However, even if the age-based default rule was optimal on average, there could be many employees who are swept up into a plan that is not optimal for them. The organizations studied by Yang (2005) and Brown and Weisbenner (2009) designated the DB plan as the default for all employees. Like Goda and Manchester, Yang finds that the default is very influential, especially for employees younger than 30 , whom she calculates are least likely to benefit from being in the DB plan. ${ }^{18}$ Brown and Weisbenner also find that the default is powerful, and employees who opt out of the default tend to choose a dominated non-default plan.

Instead of having a default, employees could be required to actively choose their primary plan before a deadline. Carroll et al. (2009) study such a regime in a private 401(k) plan that required employees to actively choose a (possibly zero) contribution rate within 30 days of hire. This approach prevents employees from finding themselves in an inappropriate plan through passivity, but also places a heavy burden on employees to gather enough information to make a wise decision. Thus, active decision regimes are best accompanied by mechanisms that help employees quickly and easily understand their options.

An interesting design choice is whether to make the plan choice reversible. In some states, the plan choice is irreversible, whereas in other states, employees have one or more opportunities to switch between plans. Reversibility may complicate the decision-making task

\footnotetext{
${ }^{18}$ This result is consistent with the findings of Beshears, Choi, Laibson and Madrian (2010b), who find that employees who accept a sub-optimal default contribution rate tend to be of lower socio-economic status.
} 
even further, and could cause employees to make their initial choice less thoughtfully. On the other hand, flexibility is valuable if employees make a mistake in their initial choice, or if their circumstances change.

All states with a DC-only plan remove at least one layer of complexity by automatically enrolling employees in the DC plan with an employer contribution that is not contingent on employee choices. Most go a step further by also requiring a fixed contribution on the part of employees, some at relatively high rates. The default investment fund in these plans is typically a target date fund. Although target date funds are not perfect, they are diversified across multiple asset classes and automatically become less risky as the participant ages. ${ }^{19}$

The complexity in public DC plans comes from the optional supplemental savings plans, in which employees must determine their appropriate contribution rates and asset allocations. As noted in Section I, not all DB and primary DC plans generate high retirement income replacement rates for all public sector workers, resulting in the need to utilize these supplemental plans. Some aspects of the supplemental plans' complexity seem unnecessary. For example, a state may have one provider administering its primary DC plan with one set of investment options, another provider with a completely different set of investment options managing its first supplemental plan, and yet another provider with a third set of investment options for its second supplemental plan. If there are multiple supplemental plans, employees who want to augment their primary benefits would have to choose which supplemental plan to use first. Like the choice between a DB and a DC plan discussed above, this is not necessarily a straightforward decision.

Another source of complexity in both DB and DC plans is the process of transforming accumulated benefits into retirement income. Most private sector DC plans do not have an annuitization option within the plan, so accumulated balances are not automatically converted into a payment stream upon retirement. Rather, retirees must take some action to convert their plan balances into an annuity, or they must self-manage spending down their wealth in retirement. In the private sector DC plans that do offer an annuity option, the take-up rate of this option is quite low. The low rate of annuitization both within and outside of DC plans is often referred to as the "annuity puzzle" because it goes against theoretical predictions that individuals

\footnotetext{
${ }^{19}$ Mitchell, Mottola, Utkus, and Yamaguchi (2007) find that 401(k) participants who are 100\% invested in a target date fund tend to have the target date fund as their asset allocation default. Nessmith and Utkus (2008) find that just over half of target date fund 401(k) investors allocate their entire 401(k) to that one target date fund, while the remaining target date investors combine the target date fund with other investment options.
} 
should have a strong demand for annuities to insure against longevity risk (Yaari, 1965; Brown, 2007). ${ }^{20}$ Within-plan annuitization options are somewhat more prevalent in the public sector than in the private sector. Of the 12 states that have a DC-only or a hybrid DB/DC plan, half have an option within the plan for employees to annuitize their wealth upon retirement. ${ }^{21}$

In contrast, both private and public sector DB plans have traditionally paid out accrued benefits as either a single or as a joint and survivor life annuity. But many DB plans have started to offer a lump sum payout option. Mitchell (1999) reports that in 1991, when aggregate data on lump sum payout options were first collected, only $14 \%$ of private sector DB plan participants had the option of a lump sum payout. By 2005, more than half (52\%) of private sector DB plan participants had a lump sum option available (U.S. Department of Labor, Bureau of Labor Statistics, 2007). Anecdotal discussions with those in the pension and retirement savings industry suggest that when a lump sum option is available, the majority of participants elect the lump sum. So the trend in private sector DB plans is towards decreased levels of annuitization. Public sector DB plans are still more aggressive in promoting annuitization. Only a third of states allow employees the option of taking a lump sum withdrawal, and in most of these, the lump-sum payout is limited to the equivalent of a few years of annuitized benefits. ${ }^{22}$

\section{Conclusions}

In this paper, we have provided an overview of the public sector pension landscape in the U.S. Although DB plans remain the predominant primary plan, some jurisdictions - particularly at the state level — have opted to offer only a DC plan or have given employees a choice among a DB, DC, and hybrid DB/DC plans. All jurisdictions have one or more supplemental DC plans available to employees.

\footnotetext{
${ }^{20}$ Chalmers and Reuter (2009) and Previtero (2010) show that annuitization rates vary negatively with recent equity market returns, perhaps reflecting shifts in workers' confidence in their ability to generate high returns by investing their savings on their own. Hu and Scott (2007), Brown, Kling, Mullainathan and Wrobel (2008), and Agnew, Anderson, Gerlach and Szykman (2008) argue that annuity demand is affected by framing, i.e., the arbitrary mental filter through which individuals interpret the annuity choice.

${ }^{21}$ Alaska, Florida, Georgia, Indiana, and Washington have a mechanism for converting DC balances into an annuity. Michigan facilitates annuitization of DC balances through a platform that gives participants competing quotes from several different annuity providers.

${ }^{22}$ Retirees may take their entire benefit as a lump sum in Delaware, Kentucky, Pennsylvania and South Dakota. In Oregon and Wisconsin, retirees may only take their entire benefit as a lump sum if the monthly annuity benefit to which they are entitled is below a low threshold. The following states allow a partial lump sum payout: Arizona, Georgia, Kansas, Louisiana, Mississippi, Missouri, North Dakota, Ohio, Texas, Utah and Virginia.
} 
We document substantial heterogeneity across jurisdictions in the extent to which their DB, DC, or hybrid DB/DC plans automatically set employees up for high retirement income replacement rates. Employees in plans that will provide them with less automatic savings probably need to engage in some supplemental savings in order to maintain their standard of living in retirement. The need for supplemental savings is particularly high for low-tenured workers who may not vest in a DB plan or who may only partially vest in a DC plan.

We conclude by discussing how recent behavioral economics research on savings and investing behavior applies to the institutions and choices that employees face in public sector retirement plans. Most public sector DC plans do not allow employees any choice in how much gets contributed to the plan, and employees' assets are directed by default into target date retirement funds. By limiting the amount of choice employees have in the primary DC plan, public sector retirement plan designers are likely to have eliminated most of the left tail of savings outcomes that arise in private sector DC plans due to financial illiteracy, procrastination, and time-inconsistent tastes for immediate consumption gratification, although it is unknown how large of a welfare cost reducing choice exacts due to rational employees' reduced ability to smooth marginal utility intertemporally. Public sector supplemental DC plans are typically more complicated and confusing than those found in the private sector, since there are often multiple supplemental plans offered, and since each supplemental plan may be operated by a different financial services company. More research is needed to determine why the supplemental plans are structured as they are and how variation in their structure affects how well public sector employees do when faced with these types of choices. 


\section{References}

Agnew, J.R., Anderson, L.R., Gerlach, J.R. and Szykman, L.R., 2008. Who Chooses Annuities: An Experimental Investigation of Gender, Framing and Defaults. American Economic Review 98(2), pp. 418-422.

Applied Research and Consulting, 2009. Financial Capability in the United States, [online]. Available at:

<http://www.finrafoundation.org/web/groups/foundation/@ foundation/documents/foundation/p1 20536.pdf $>$ [Accessed 9 August 2010].

Benartzi, S., 2001. Excessive Extrapolation and the Allocation of 401(k) Accounts to Company Stock? Journal of Finance 56(5), pp. 1747-1764.

Benartzi, S. and Thaler, R.H., 2001. Naive Diversification Strategies in Retirement Saving Plans. American Economic Review 91(1), pp. 79-98.

Benartzi, S. and Thaler, R.H., 2007. Heuristics and Biases in Retirement Savings Behavior. Journal of Economic Perspectives, 21(3), pp. 81-104.

Beshears, J, Choi, J.J., Laibson, D., and Madrian, B.C. 2008. The Importance of Default Options for Retirement Saving Outcomes: Evidence from the United States. In: S.J. Kay and T. Sinha eds. Lessons from Pension Reform in the Americas. Oxford: Oxford University Press, pp. 59-87.

Beshears, J, Choi, J.J., Laibson, D. and Madrian, B.C., 2010a. Simplification and Saving. NBER Working Paper No. 12659.

Beshears, J. Choi, J.J., Laibson, D. and Madrian, B.C., 2010b. The Limitations of Defaults. Harvard University working paper.

Brown, J.R., 2007. Rational and Behavioral Perspectives on the Role of Annuities in Retirement Planning. NBER Working Paper No. 13537.

Brown, J.R., Kling, J.R., Mullainathan, S. and Wrobel, M.V., 2008. Why Don't People Insure Late-Life Consumption? A Framing Explanation of the Under-Annuitization Puzzle. American Economic Review 98(2), pp. 304-309.

Brown, J.R., Liang, N. and Weisbenner, S., 2007. Individual Account Investment Options and Portfolio Choice: Behavioral Lessons from 401(k) Plans." Journal of Public Economics 91(10), pp. 1992-2013.

Brown, J.R. and Weisbenner, S., 2009. Who Chooses Defined Contribution Plans? In: J.R. Brown, J.B. Liebman and D.A. Wise, eds. Social Security Policy in a Changing Environment. Chicago, IL: University of Chicago Press, pp. 131-161. 
Calvet, L.E., Campbell, J.Y. Sodini, P., 2009. Measuring the Financial Sophistication of Households. American Economic Review 99(2), pp. 393-98.

Card, D. and Ransom, M. (forthcoming). Pension Plan Characteristics and Framing Effects in Employee Savings Behavior. Review of Economics and Statistics.

Carroll, G.D., Choi, J.J., Laibson, D., Madrian, B.C. and Metrick, A., 2009. Optimal Defaults and Active Decisions. Quarterly Journal of Economics, 124(4), pp. 1639-1674.

Chalmers, J. and Reuter, J., 2009. How Do Retirees Value Life Annuities? Evidence from Public Employees. NBER Working Paper No. 15608.

Chan, S. and Stevens, A.H., 2008. What You Don't Know Can't Help You: Worker Knowledge and Retirement Decision-Making. Review of Economics and Statistics, 90(2), pp. 253-266.

Choi, J.J., Laibson, D. and Madrian, B.C., 2004. Plan Design and 401(k) Savings Outcomes. National Tax Journal, 57(2), pp. 275-298.

Choi, J.J., Laibson, D. and Madrian, B.C., 2009a. Reducing the Complexity Costs of 401(k) Participation Through Quick Enrollment. In: D.A. Wise, ed. Developments in the Economics of Aging. Chicago: University of Chicago Press, pp. 57-85.

Choi, J.J., Laibson, D. and Madrian, B.C., 2009b. Mental Accounting in Portfolio Choice: Evidence from a Flypaper Effect. American Economic Review, 99(5), pp. 2085-2095.

Choi, J.J., Laibson, D. and Madrian, B.C., 2010. Why Does the Law of One Price Fail? An Experiment on Index Mutual Funds. Review of Financial Studies 23(4), pp. 1405-1432.

Choi, J.J., Laibson, D. and Madrian, B.C., forthcoming. \$100 Bills on the Sidewalk: Suboptimal Investment in 401(k) Plans. Review of Economics and Statistics.

Choi, J.J., Laibson, D., Madrian, B.C. and Metrick, A., 2004. Employees' Investment Decisions About Company Stock. In: O.S. Mitchell and S. P. Utkus, eds. Pension Design and Structure. New York: Oxford University Press, pp. 121-36.

Choi, J.J., Laibson, D., Madrian, B.C. and Metrick, A., 2005. Passive Decisions and Potent Defaults. In: D.A. Wise, ed. Analyses in the Economics of Aging. Chicago: University of Chicago Press, pp. 59-78.

Choi, J.J., Laibson, D., Madrian, B.C. and Metrick, A., 2006. Saving for Retirement on the Path of Least Resistance. In E.J. McCaffrey and J. Slemrod, eds. Behavioral Public Finance: Toward a New Agenda. New York: Russell Sage Foundation, pp. 304-351.

Choi, J.J., Laibson, D., Madrian, B.C. and Metrick, A., 2009. Reinforcement Learning and Savings Behavior. Journal of Finance 64(6), pp. 2515-2534. 
Engen, E. M., Gale, W.G. and Uccello, C.R., 1999. The Adequacy of Retirement Saving. Brookings Papers on Economic Activity 2, pp. 65-188.

Goda, G. S. and Manchester, C.F., 2010. Incorporating Employee Heterogeneity into Default Rules for Retirement Plan Selection. NBER Working Paper No. 16099.

Gustman, A.L., Steinmeier, T.L. and Tabatabai, N., 2007. Imperfect Knowledge of Plan Type. NBER Working Paper No. 13379.

Holden, K. C. and Nicholson, S., 1998. Selection of a Joint-and-Survivor Pension. Institute for Research on Poverty Discussion Paper No. 1175-98. University of Wisconsin, Madison.

Hu, W.Y. and Scott, J.S., 2007. Behavioral Obstacles in the Annuity Market. Financial Analysts Journal, 63(6), pp. 71-82.

Huberman, G. and Jiang, W., 2006. Offering vs. Choice by 401(k) Plan Participants: Equity Exposure and Number of Funds. Journal of Finance 61(2), pp. 763-801.

Karlsson, A., Massa, M. Simonov, A., 2007. Pension Portfolio Choice and Menu Exposure. In: O.S. Mitchell, B.J. Soldo and B.C. Madrian, eds. Redefining Retirement: How Will Boomers Fare? Oxford University Press, pp. 248-271.

Lusardi, A. and Mitchell, O.S., 2006. Financial Literacy and Planning: Implications for Retirement Wellbeing. Pension Research Council Working Paper 2006-1.

Lusardi, A. and Mitchell, O.S., 2007. Financial Literacy and Retirement Preparedness: Evidence and Implications for Financial Education. Business Economics 42(1), pp. 35-44.

Lusardi, A., Mitchell, O.S., and Curto, V., 2010. Financial Literacy among the Young. Journal of Consumer Affairs, 44(2), pp. 358-380.

Lusardi, A. and Tufano, P. 2009. Debt Literacy, Financial Experiences, and Overindebtedness. NBER Working Paper No. 14808.

Madrian, B.C., and Shea, D.F., 2001. The Power of Suggestion: Inertia in 401(k) Participation and Savings Behavior. Quarterly Journal of Economics, 116(4), pp. 1149-1187.

Maine Unified Retirement Plan Task Force, 2010. Task Force Study and Report: Maine State Employee and Teacher Unified Retirement Plan. MainePERS.

Mitchell, O.S., 1999. New Trends in Pension Benefit and Retirement Provisions. NBER Working Paper No. 7381.

Mitchell, O.S., Mottola, G.R., Utkus, S.P. and Yamaguchi, T. 2007. The Dynamics of Lifecycle Investing in 401(k) Plans. Pension Research Council Working Paper 2007-28. 
Munnell, A.H. and Soto, M., 2005. What Replacement Rates Do Households Actually Experience in Retirement? Boston College Center for Retirement Research Working Paper 200510.

Munnell, A.H. and Sundén, A., 2004. Coming up Short: The Challenge of 401(k) Plans. Washington, D.C.: The Brookings Institution Press.

Munnell, A.H., Webb, A. and Golub-Sass, F., 2007. Is There Really A Retirement Saving Crisis? An NRRI Analysis. Boston College Center for Retirement Research Issue Brief 7-11.

Nessmith, W.E. and Utkus, S.P., 2008. Target-date Funds: Plan and Participation Adoption in 2007. Vanguard Center for Retirement Research, 33.

Pensions \& Investments, 2010a. The P\&I 1000: Largest Retirement Funds. Data set available from $<$ http://www.pionline.com/section/datastore\#pi1000> [Accessed 7 July 2010].

Pensions \& Investments, 2010b. The P\&I 1000. Pensions \& Investments, Vol. 38(3), p. 13.

Previtero, A., 2010. Stock Market Returns and Annuitization. Working Paper.

Saku, A., 2005. Does the Balance of Power Within a Family Matter? The Case of the Retirement Equity Act. Journal of Public Economics, 89(9-10), pp. 1699-717.

Scholz, J.K., Seshadri, A. and Khitatrakun, S., 2006. Are Americans Saving 'Optimally' for Retirement? Journal of Political Economy, 114(4), pp. 607-43.

Snell, R., 2010a. Pension Reform: Not Easy, but Worth It. State Legislatures, [online] July/August, pp. 32-34. Available at: 〈http://www.ncsl.org/?tabid=20716> [Accessed 6 August 2010].

Snell, R., 2010b. State Defined Contribution and Hybrid Pension Plans. National Conference of State Legislatures, [online]. Available at:

$<$ http://www.ncsl.org/LinkClick.aspx?fileticket=yGsmFhwoq7E\%3d\&tabid=18511 > [Accessed 6 August 2010].

Thaler, R.H. and Benartzi, S., 2004. Save More Tomorrow: Using Behavioral Economics to Increase Employee Savings. Journal of Political Economy, 112(S1), pp. S164-S187.

U.S. Department of Labor, Employee Benefit Security Administration, 2008. Private Pension Plan Bulletin Historical Tables, [online]. Available at:

<http://www.dol.gov/ebsa/pdf/privatepensionplanbulletinhistoricaltables.pdf> [Accessed 13 December 2007].

U.S. Department of Labor, Employee Benefit Security Administration, 2010. Private Pension Plan Bulletin: Abstract of 2007 Form 5500 Annual Reports, [online]. Available at: $<$ http://www.dol.gov/ebsa/pdf/2007pensionplanbulletin.pdf $>$ [Accessed 4 August 2010]. 
U.S. Department of Labor, Bureau of Labor Statistics, 2007. National Compensation Survey: Employee Benefits in Private Industry in the United States, 2005 [online]. Available at: <http://www.bls.gov/ncs/ebs/sp/ebbl0022.pdf > [Accessed 18 January 2011].

U.S. Census Bureau, Number and Membership of State and Local Public Employee Retirement Systems by State: Fiscal Year 2008 [online]. Available at: <http://www.census.gov/govs/retire/2008ret05a.html> [Accessed 4 August 2010].

Yaari, M.E., 1965. Uncertain Lifetime, Life Insurance, and the Theory of the Consumer. Review of Economic Studies, 32(2), pp. 137-50.

Yang, T.S., 2005. Understanding the Defined Benefit versus Defined Contribution Choice. Pension Research Council Working Paper 2005-4. 


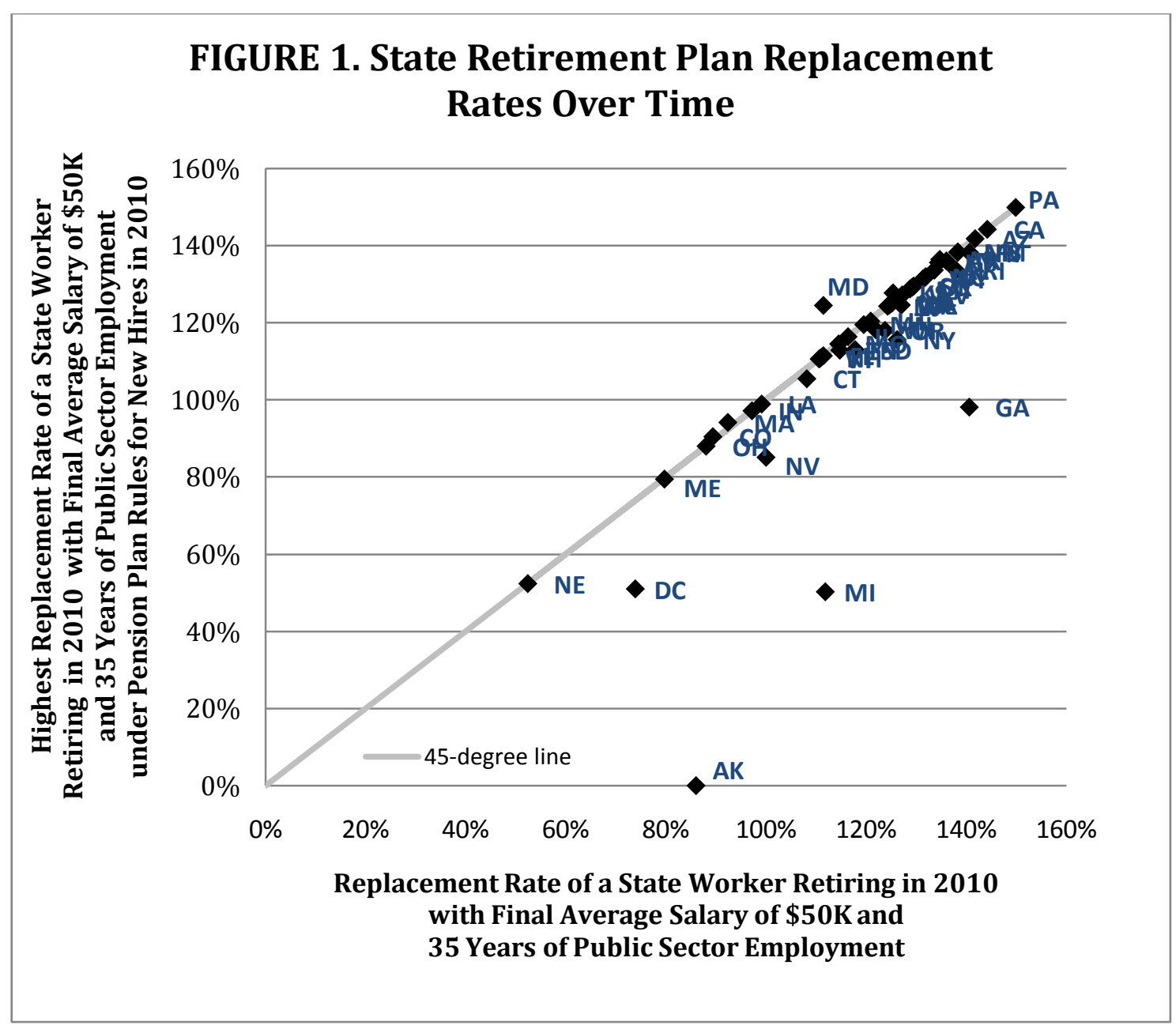


Table 1A. Primary Retirement and Savings Plans Available to Newly Hired General State Employees

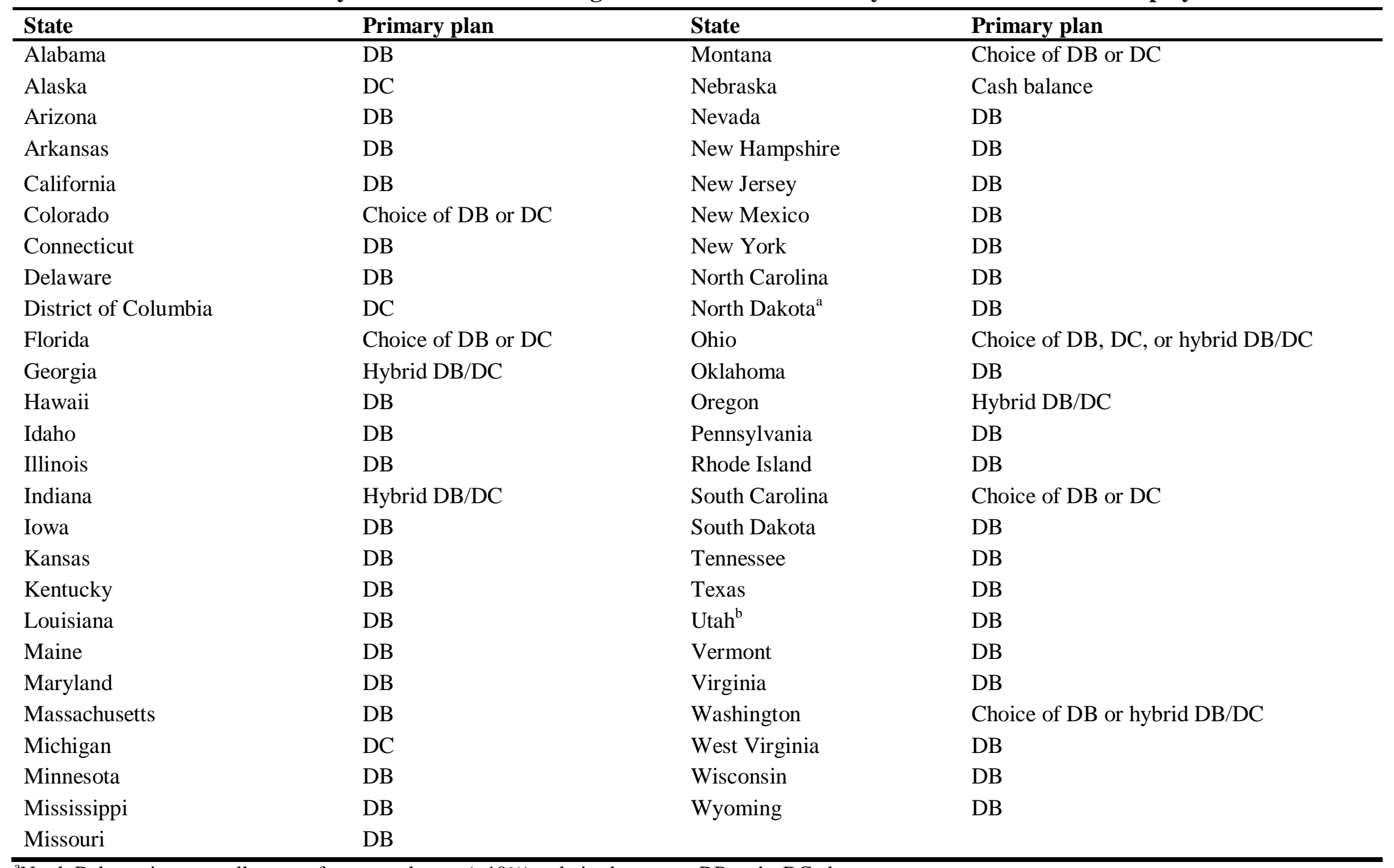

${ }^{\mathrm{a}}$ North Dakota gives a small group of state employees $(<10 \%)$ a choice between a DB and a DC plan.

${ }^{\mathrm{b}}$ Starting in 2011, Utah state employees will have a choice between a hybrid DB/DC plan and a DC plan. 
Table 1B. Primary Retirement and Savings Plans Available to Newly Hired General County and City Employees

\begin{tabular}{llll}
\hline County & Primary plan & City & Primary plan \\
\hline Los Angeles County, CA & DB & New York City, NY & DB \\
Cook County, IL & DB & Los Angeles, CA & DB \\
Harris County, TX & Cash balance & Chicago, IL & DB \\
Maricopa County, AZ & DB & Houston, TX & DB \\
Orange County, CA & Choice of DB or hybrid DB/DC & Phoenix & DB \\
San Diego County, CA & DB & Philadelphia, PA & DB \\
Kings County, NY & DB & San Antonio, TX & Cash balance \\
Miami-Dade County, FL & DB & Dallas, TX & DB \\
Dallas County, TX & Cash balance & San Diego, CA & Hybrid DB/DC \\
Queens County, NY & DB & San Jose, CA & DB \\
Wayne County, MI & Hybrid DB/DC & Detroit, MI & DB \\
San Bernardino County, CA & DB & San Francisco, CA & DB \\
Riverside County, CA & DB & Jacksonville, FL & Choice of DB or DC \\
King County, WA & Choice of DB or hybrid DB/DC & Indianapolis, IN & Hybrid DB/DC \\
Broward County, FL & DB & Austin, TX & DB \\
Clark County, NV & DB & Columbus, OH & Choice of DB, DC, or Hybrid DB/DC \\
Santa Clara County, CA & DB & Fort Worth, TX & DB \\
Tarrant County, TX & Cash balance & Charlotte, NC & DB \\
New York County, NY & DB & Memphis, TN & DB \\
Bexar County, TX & Cash balance & Boston, MA & DB \\
\hline
\end{tabular}


Table 2. Joe the Bachelor's Automatic Retirement Income Replacement Rates: Summary Statistics

\begin{tabular}{|c|c|c|c|c|c|c|}
\hline & \multicolumn{6}{|c|}{ Work history scenario } \\
\hline & $\mathrm{A}$ & $\mathrm{B}$ & $\mathrm{C}$ & $\mathrm{D}$ & $\mathrm{E}$ & $\mathrm{F}$ \\
\hline & 0 yrs. private & 0 yrs. private & 5 yrs. private & 30 yrs. private & 15 yrs. private & 20 yrs. public \\
\hline & 40 yrs. public & 35 yrs. public & 30 yrs. public & 5 yrs. public & 20 yrs. public & 15 yrs. private \\
\hline & \multicolumn{6}{|c|}{$\$ 50,000$ final salary } \\
\hline \multicolumn{7}{|l|}{ DB-only plans } \\
\hline Minimum replacement rate & $85 \%$ & $79 \%$ & $69 \%$ & $42 \%$ & $65 \%$ & $48 \%$ \\
\hline Mean replacement rate & $129 \%$ & $121 \%$ & $113 \%$ & $61 \%$ & $96 \%$ & $76 \%$ \\
\hline Maximum replacement rate & $163 \%$ & $150 \%$ & $138 \%$ & $74 \%$ & $122 \%$ & $98 \%$ \\
\hline \multicolumn{7}{|l|}{ Hybrid $D B / D C$ plans } \\
\hline Minimum replacement rate & $51 \%$ & $44 \%$ & $37 \%$ & $49 \%$ & $41 \%$ & $33 \%$ \\
\hline Mean replacement rate & $96 \%$ & $90 \%$ & $84 \%$ & $55 \%$ & $75 \%$ & $62 \%$ \\
\hline Maximum replacement rate & $125 \%$ & $118 \%$ & $111 \%$ & $66 \%$ & $95 \%$ & $79 \%$ \\
\hline \multicolumn{7}{|l|}{ DC-only plans } \\
\hline Minimum replacement rate & $0 \%$ & $0 \%$ & $0 \%$ & $41 \%$ & $15 \%$ & $18 \%$ \\
\hline Mean replacement rate & $32 \%$ & $32 \%$ & $32 \%$ & $48 \%$ & $38 \%$ & $39 \%$ \\
\hline \multirow[t]{2}{*}{ Maximum replacement rate } & $53 \%$ & $53 \%$ & $53 \%$ & $53 \%$ & $53 \%$ & $53 \%$ \\
\hline & \multicolumn{6}{|c|}{$\$ 100,000$ final salary } \\
\hline \multicolumn{7}{|l|}{ DB-only plans } \\
\hline Minimum replacement rate & $86 \%$ & $80 \%$ & $70 \%$ & $34 \%$ & $63 \%$ & $49 \%$ \\
\hline Mean replacement rate & $120 \%$ & $111 \%$ & $101 \%$ & $50 \%$ & $83 \%$ & $66 \%$ \\
\hline Maximum replacement rate & $154 \%$ & $141 \%$ & $129 \%$ & $64 \%$ & $107 \%$ & $83 \%$ \\
\hline \multicolumn{7}{|l|}{ Hybrid $D B / D C$ plans } \\
\hline Minimum replacement rate & $53 \%$ & $46 \%$ & $38 \%$ & $38 \%$ & $43 \%$ & $35 \%$ \\
\hline Mean replacement rate & $84 \%$ & $78 \%$ & $72 \%$ & $44 \%$ & $64 \%$ & $54 \%$ \\
\hline Maximum replacement rate & $109 \%$ & $101 \%$ & $93 \%$ & $54 \%$ & $81 \%$ & $67 \%$ \\
\hline \multicolumn{7}{|l|}{ DC-only plans } \\
\hline Minimum replacement rate & $0 \%$ & $0 \%$ & $0 \%$ & $32 \%$ & $15 \%$ & $18 \%$ \\
\hline Mean replacement rate & $24 \%$ & $24 \%$ & $24 \%$ & $37 \%$ & $30 \%$ & $31 \%$ \\
\hline Maximum replacement rate & $41 \%$ & $41 \%$ & $31 \%$ & $41 \%$ & $41 \%$ & $41 \%$ \\
\hline
\end{tabular}

Source: Authors' calculations. 
Table 3. Characteristics of State Primary Defined Contribution Retirement Savings Plans

\begin{tabular}{|c|c|c|c|c|c|}
\hline & \multicolumn{5}{|c|}{ States with primary DC plan only } \\
\hline & Participation & $\begin{array}{l}\text { Employee } \\
\text { contributions }\end{array}$ & $\begin{array}{l}\text { Employer } \\
\text { contributions }\end{array}$ & $\begin{array}{l}\text { Investment } \\
\text { options }\end{array}$ & Vesting \\
\hline Alaska & $\begin{array}{l}\text { Automatic and } \\
\text { immediate }\end{array}$ & Mandatory $8 \%$ & $\begin{array}{l}5 \% \text { non-contingent } \\
\text { contribution }\end{array}$ & $\begin{array}{l}10 \text { funds, target date } \\
\text { fund default }\end{array}$ & $\begin{array}{l}100 \% \text { after } 5 \text { years } \\
0-0-25-50-75-100\end{array}$ \\
\hline Michigan & $\begin{array}{l}\text { Automatic and } \\
\text { immediate }\end{array}$ & Optional up to $100 \%$ & $\begin{array}{l}4 \% \text { non-contingent } \\
\text { contribution; } 100 \% \text { match } \\
\text { on employee contributions } \\
\text { up to } 3 \% \text { of pay }\end{array}$ & $\begin{array}{l}22 \text { funds, fixed } \\
\text { income default }\end{array}$ & $\begin{array}{l}100 \% \text { after } 4 \text { years } \\
0-0-50-75-100\end{array}$ \\
\hline \multirow[t]{3}{*}{ Washington DC } & $\begin{array}{l}\text { Automatic } \\
\text { after } 1 \text { yr. service }\end{array}$ & None & $\begin{array}{l}5 \% \text { non-contingent } \\
\text { contribution }\end{array}$ & $\begin{array}{l}17 \text { funds, target date } \\
\text { fund default }\end{array}$ & $\begin{array}{l}100 \% \text { after } 5 \text { years } \\
0-0-20-40-60-100\end{array}$ \\
\hline & \multicolumn{5}{|c|}{ States with choice of primary plan that includes DC-only option } \\
\hline & Participation & $\begin{array}{l}\text { Employee } \\
\text { contributions }\end{array}$ & $\begin{array}{l}\text { Employer } \\
\text { Contributions }\end{array}$ & $\begin{array}{l}\text { Investment } \\
\text { Options }\end{array}$ & Vesting \\
\hline Colorado & Opt-in & $\begin{array}{l}\text { Mandatory } 8 \% \text { if DC } \\
\text { plan chosen }\end{array}$ & $\begin{array}{l}10.15 \% \text { non-contingent } \\
\text { contribution }\end{array}$ & $\begin{array}{l}21 \text { funds, balanced } \\
\text { fund default }\end{array}$ & $\begin{array}{l}100 \% \text { after } 5 \text { years } \\
50-60-70-80-90-100\end{array}$ \\
\hline Florida & Opt-in & None & $\begin{array}{l}9 \% \text { non-contingent } \\
\text { contribution }\end{array}$ & $\begin{array}{l}20 \text { funds, balanced } \\
\text { fund default }\end{array}$ & $\begin{array}{l}100 \% \text { after } 1 \text { year } \\
0-100\end{array}$ \\
\hline Montana & Opt-in & $\begin{array}{l}\text { Mandatory } 6.9 \% \text { if } \\
\text { DC plan chosen }\end{array}$ & $\begin{array}{l}4.19 \% \text { non-contingent } \\
\text { contribution }\end{array}$ & $\begin{array}{l}15 \text { funds, balanced } \\
\text { fund default }\end{array}$ & $\begin{array}{l}100 \% \text { after } 5 \text { years } \\
0-0-0-0-0-100\end{array}$ \\
\hline North Dakota ${ }^{a}$ & Opt-in & $\begin{array}{l}\text { Mandatory } 4 \% \text { if DC } \\
\text { plan chosen }\end{array}$ & $\begin{array}{l}4.12 \% \text { non-contingent } \\
\text { contribution }\end{array}$ & $\begin{array}{l}20 \text { funds + brokerage } \\
\text { window, default } \\
\text { unspecified }\end{array}$ & $\begin{array}{l}100 \% \text { after } 4 \text { years } \\
0-0-50-75-100\end{array}$ \\
\hline South Carolina & Opt-in & $\begin{array}{l}\text { Mandatory } 6.5 \% \text { if } \\
\text { DC plan chosen }\end{array}$ & $\begin{array}{l}5 \% \text { non-contingent } \\
\text { contribution }\end{array}$ & $\begin{array}{l}83 \text { funds, target date } \\
\text { default fund }\end{array}$ & Immediate \\
\hline Ohio & Opt-in & $\begin{array}{l}\text { Mandatory } 10 \% \text { if } \\
\text { DC plan chosen }\end{array}$ & $\begin{array}{l}8.73 \% \text { non-contingent } \\
\text { contribution }\end{array}$ & $\begin{array}{l}16 \text { funds, target date } \\
\text { default fund }\end{array}$ & $\begin{array}{l}100 \% \text { after } 5 \text { years } \\
0-20-40-60-80-100\end{array}$ \\
\hline Utah (starts 2011) & NA & Allowed & $\begin{array}{l}10 \% \text { non-contingent } \\
\text { contribution }\end{array}$ & NA & $100 \%$ after 4 years \\
\hline
\end{tabular}

${ }^{\mathrm{a}}$ North Dakota gives a small group of state employees $(<10 \%)$ a choice between a DB and a DC plan. 


\section{Appendix A: Calculation of Retirement Income Replacement Rates}

Our calculation of the automatic retirement income replacement rates used in Table 2 (and Appendix Table B1) incorporates both the defined benefit pension and Social Security income available to state retirees. We do not transform accumulated defined contribution retirement wealth into an income stream in retirement.

\section{Assumptions}

Our calculations of automatic retirement income replacement rates are based on a stylized public sector employee, Joe the Bachelor. We make the following assumptions:

- Joe was born on January 2, $1945^{1}$ and entered the labor force in either 1970 (if he has a 40 year career) or 1975 (if he has a 35 year career).

- Joe retires on December 31,2009 , just before his $65^{\text {th }}$ birthday, so that he has no labor income in the year in which he turns 65 .

- Joe is single when he retires, has never been married, and has no dependents.

- Joe's earnings trajectory is independent of the sector in which he is employed.

- Joe retires with a final average salary of either $\$ 50,000$ or $\$ 100,000$.

- Joe's earnings grow at a real annual rate of 1 percent until age 60 , at which point his earnings are constant in nominal terms at either $\$ 50,000$ or $\$ 100,000$ until he retires. This makes Joe's final average salary, which is used in the defined benefit pension formulas, the same as his final salary in the majority of states.

- We calculate Joe's nominal wage profile up until age 60 from his real wage profile using the Social Security Administration wage index factors. Note that Social Security only indexes wages up through age 60.

- In calculating Joe's defined benefit pension income, we assume that Joe was covered throughout his career by the plan rules in effect for newly eligible employees in 2010.

- In Figure 1, we also calculate Joe's defined benefit pension income assuming that Joe was covered by the plan rules in effect for newly eligible employees on January 1, 1975.

\footnotetext{
${ }^{1}$ We assume that Joe's birthday is on January 2, 1945 rather than January 1, 1945 because federal tax law uses Joe's age on January 1 in determining whether Joe can claim an additional exemption for being age 65 in the computation of Joe's tax liability for the previous calendar year. Tax laws in several states have a similar provision.
} 


\section{Calculating Defined Benefit Pension Income for State Employees}

We calculate the public pension benefits for all states (plus the District of Columbia) that have either a defined benefit or a hybrid DB/DC plan for their general employees. If a state retirement plan has a hybrid DB/DC structure, we only count the defined benefit portion of the available retirement benefit towards the automatic replacement rate. The state's pension contribution to the automatic replacement rate is zero for states with defined contribution or cash balance plans. It is also zero for the defined contribution portion of states' hybrid DB/DC plans.

If Joe does not satisfy his plan's vesting rules under a particular scenario, then he is ineligible to receive a pension benefit. If Joe satisfies the vesting rules, we calculate his normal, unreduced yearly retirement benefit using the plan rules in place for newly eligible employees in 2010. Even though Joe is not a newly eligible employee in 2010, this gives us a measure of the pension plan generosity in place for new employees like Joe going forward. For Figure 1, we also calculate the pension benefit Joe would receive under the plan rules in place for newly eligible employees on January 1, 1975. If the state subsequently increased its pension plan generosity, we assume that Joe switched to the newer plan that provides a greater future retirement benefit if he is offered the option of changing plans.

For every scenario, we calculate Joe's pension income assuming a pre-retirement final salary of $\$ 50,000$ or $\$ 100,000$. We calculate Joe's final average salary, which is used in each state's defined benefit pension benefit formula, from Joe's nominal earnings profile. His years of credited service consist solely of his public sector tenure, which varies by scenario. Once we have calculated the yearly pension benefit provided by each plan, we compare these amounts with the plan's minimum and maximum allowances, if they exist, and modify his pension benefits if necessary to satisfy these constraints.

\section{Calculating Social Security Benefits for State Employees}

We assume that Joe claims his Social Security benefit when he retires in 2010 at age 65 . In order to calculate the benefit amount, we take the lower of Joe's nominal earnings and the maximum Social Security taxable earnings for each year of his career. We index the resulting values by multiplying them by the Social Security Administration wage index factors. To obtain Joe's average indexed monthly earnings (AIME), we sum the 35 years of highest indexed 
earnings, divide by 420 (= 35 years $\times 12$ months), and round to the nearest lower dollar. Using the 2007 bend points of $\$ 680$ and $\$ 4,100$, we multiply the first $\$ 680$ of the AIME by 0.9, the amount over $\$ 680$ and less than or equal to $\$ 4,100$ by 0.32 , and the amount over $\$ 4,100$ by 0.15 . We add the three values generated from the previous step and round to the nearest lower 10 cents to get the primary insurance amount (PIA). To account for cost-of-living adjustments (COLAs), the PIA is increased beginning in 2007, the year that Joe reaches age 62. We multiply his PIA by the 2007 COLA factor and round the resulting amount to the nearest lower 10 cents. We repeat this process using the 2008 COLA factor. In effect, we obtain the full monthly Social Security benefit. However, since Joe chooses to receive his benefit prior to reaching the normal Social Security retirement age of 66 for individuals in his birth cohort, his benefit is reduced. In Joe's case, his benefit is reduced by $5 / 9$ of 1 percent for each of the 12 months that he receives a benefit before age 66. After making this reduction, we multiply the revised monthly benefit by 12 to obtain his annual Social Security benefit.

In states whose general employees are covered by Social Security, Joe is entitled to the above benefit. In states whose employees do not participate in Social Security, Joe only receives a Social Security benefit if he has at least 10 years of substantial earnings through private sector employment. If Joe has fewer than 30 years of creditable earnings, Joe's benefit is reduced in accordance with the Windfall Elimination Provision (WEP). In states without Social Security participation, the WEP is relevant in scenarios E and F (in which Joe has 15 years of private sector employment and 20 years of public sector employment). Under these scenarios in states without Social Security participation, we change the 0.9 multiplicative factor for the first 2007 bend point to 0.4 and compute the resulting Social Security benefit.

\section{Calculating State and Federal Income Taxes}

Before retirement, we assume that Joe's only source of income is his salary. Once Joe retires at age 65, we assume that his public pension and Social Security benefits are his only sources of income. Using the NBER's TAXSIM, we calculate Joe's federal income tax liability using the 2009 tax rules (the most recent effective tax rules). We assume that Joe takes the standard deduction and does not itemize. Because TAXSIM does not distinguish between public and private sector pensions in calculating state income tax liabilities, and because many states have preferential tax treatment for public sector pension income (Table A1), we calculate state 
liabilities on our own using the 2009 tax rules. If Joe is employed, we subtract his public sector pension contributions, if made on a pre-tax basis, from his income. We then subtract the applicable state-level personal exemption and standard deduction from his salary to calculate his state-level taxable income before retirement. If Joe is retired, we first subtract state individual income exemptions for public pensions and Social Security, if applicable, from Joe's respective public pension income and Social Security income. Next, we add together the remaining taxable pension and Social Security income. We then subtract applicable state-level personal exemptions and standard deductions, giving us Joe's post-retirement taxable income at the state level. For both employed Joe and retired Joe, if Joe's state taxable income is zero or negative, we assume that he has zero state individual income tax liability. Otherwise, we apply the state individual income tax brackets to his taxable income and calculate his initial state tax liability. From this tax liability we subtract any tax credits for which Joe is eligible (for example, some states have special tax credits for either older individuals with retirement income or for individual who are single). The remaining amount, as long as it is non-negative, represents his state individual income tax liability; otherwise, we assume that Joe has zero state tax liability.

\section{Calculating Retirement Income Replacement Rates}

The numerator of Joe's automatic retirement income replacement rate is the sum of his public pension and his Social Security benefit minus his federal and state income taxes. The denominator of his automatic replacement rate is his gross pre-retirement income. We calculate Joe's gross pre-retirement income as his public sector salary minus any mandatory state pension plan contributions and minus his federal and state income taxes and his portion of the FICA tax (for states whose employees participate in Social Security). We divide the numerator by the denominator to obtain Joe's automatic retirement income replacement rate. 
Appendix Table A1. State Participation in Social Security for Newly Hired General Public Employees and the State Taxation of Public Pension Benefits

\begin{tabular}{|c|c|c|c|}
\hline State & $\begin{array}{l}\text { Part of } \\
\text { Social } \\
\text { Security }\end{array}$ & $\begin{array}{l}\text { Has an } \\
\text { Income } \\
\text { Tax }\end{array}$ & State Taxation of State Pension Benefits \\
\hline Alabama & Yes & Yes & Public pension fully excluded from taxable income \\
\hline Alaska & No & No & No personal income tax \\
\hline Arizona & Yes & Yes & $\$ 2,500$ public pension exclusion \\
\hline Arkansas & Yes & Yes & $\$ 6,000$ public pension exclusion \\
\hline California & Yes & Yes & Public pension fully taxed \\
\hline Colorado & No & Yes & $\begin{array}{l}\$ 24,000 \text { exclusion for Social Security and public and } \\
\text { other qualified pension income for those } 65+\end{array}$ \\
\hline Connecticut & Yes & Yes & Public pension fully taxed \\
\hline Delaware & Yes & Yes & $\$ 12,500$ public pension exclusion for those $60+$ \\
\hline District of Columbia & Yes & Yes & $\$ 3,000$ pension income exclusion for those $62+$ \\
\hline Florida & Yes & No & No personal income tax \\
\hline Georgia & Yes & Yes & $\$ 35,000$ retirement income exclusion \\
\hline Hawaii & Yes & Yes & Public pension fully excluded from taxable income \\
\hline Idaho & Yes & Yes & Public pension fully taxed \\
\hline Illinois & Yes & Yes & Public pension fully excluded from taxable income \\
\hline Indiana & Yes & Yes & Public pension fully taxed \\
\hline Iowa & Yes & Yes & $\$ 24,000$ public pension exclusion \\
\hline Kansas & Yes & Yes & Public pension fully excluded from taxable income \\
\hline Kentucky & Yes & Yes & $\$ 41,110$ public pension exclusion \\
\hline Louisiana & No & Yes & Public pension fully excluded from taxable income \\
\hline Maine & No & Yes & Exclusion of $\$ 6,000$ minus Social Security benefits \\
\hline Maryland & Yes & Yes & $\$ 24,500$ pension exclusion for those $65+$ \\
\hline Massachusetts & No & Yes & Public pension fully excluded from taxable income \\
\hline Michigan & Yes & Yes & Public pension fully excluded from taxable income \\
\hline Minnesota & Yes & Yes & Public pension fully taxed \\
\hline Mississippi & Yes & Yes & Public pension fully excluded from taxable income \\
\hline Missouri & Yes & Yes & $\begin{array}{l}\text { May deduct the greater of } \$ 6,000 \text { or } 50 \% \text { of public } \\
\text { pension for those } 62+\text {; pension exemption limited to } \\
\text { the amount of Social Security income }\end{array}$ \\
\hline Montana & Yes & Yes & $\begin{array}{l}\text { Pension exclusion of up to } \$ 3,600 \text { if Adjusted Gross } \\
\text { Income }<\$ 30,000\end{array}$ \\
\hline Nebraska & Yes & Yes & Public pension fully taxed \\
\hline Nevada & No & No & No personal income tax \\
\hline New Hampshire & Yes & No & No personal income tax \\
\hline New Jersey & Yes & Yes & $\begin{array}{l}\$ 15,000 \text { pension exclusion for those age } 62+\text { if } \text { AGI } \\
\leq \$ 100,000\end{array}$ \\
\hline
\end{tabular}




\begin{tabular}{|c|c|c|c|}
\hline New Mexico & Yes & Yes & $\begin{array}{l}\text { Retirement income exclusion of up to } \$ 2,500 \text { for } \\
\text { those with AGI } \leq \$ 39,667\end{array}$ \\
\hline New York & Yes & Yes & Public pension fully excluded from taxable income \\
\hline North Carolina & Yes & Yes & $\$ 4,000$ public pension exclusion \\
\hline North Dakota & Yes & Yes & Public pension fully taxed \\
\hline Ohio & No & Yes & $\begin{array}{l}\text { Retirement income tax credit of up to } \$ 200 \text { if } \\
\text { retirement income } \geq \$ 500\end{array}$ \\
\hline Oklahoma & Yes & Yes & Retirement income exclusion of up to $\$ 10,000$ \\
\hline Oregon & Yes & Yes & $\begin{array}{l}\text { Tax credit of up to } 9 \% \text { of pension income if } \\
\text { household income }<\$ 22,500\end{array}$ \\
\hline Pennsylvania & Yes & Yes & Public pension fully excluded from taxable income \\
\hline Rhode Island & Yes & Yes & Public pension fully taxed \\
\hline South Carolina & Yes & Yes & $\begin{array}{l}\text { Public pension exclusion of up to } \$ 15,000 \text { for those } \\
65+\end{array}$ \\
\hline South Dakota & Yes & No & No personal income tax \\
\hline Tennessee & Yes & No & No personal income tax \\
\hline Texas & Yes & No & No personal income tax \\
\hline Utah & Yes & Yes & Tax credit of up to $\$ 450$ \\
\hline Vermont & Yes & Yes & Public pension fully taxed \\
\hline Virginia & Yes & Yes & Pension exclusion of up to $\$ 12,000$ for those $65+$ \\
\hline Washington & Yes & No & No personal income tax \\
\hline West Virginia & Yes & Yes & $\begin{array}{l}\$ 2,000 \text { public pension exclusion; additional } \\
\text { retirement income exclusion for those age } 65+\end{array}$ \\
\hline Wisconsin & Yes & Yes & $\begin{array}{l}\$ 5,000 \text { pension exclusion for those } 65+\text { if Adjusted } \\
\text { Gross Income }<\$ 15,000\end{array}$ \\
\hline Wyoming & Yes & No & No personal income tax \\
\hline
\end{tabular}

Note: State participation in Social Security is categorized for newly hired public sector employees. Some states in which newly hired employees are part of the Social Security system have older cohorts of employees that are not a part of Social Security. 
Appendix Figure A1. Joe the Bachelor's Retirement Income Replacement Rates under Various Scenarios

(Final Average Salary of \$50,000 Annually)
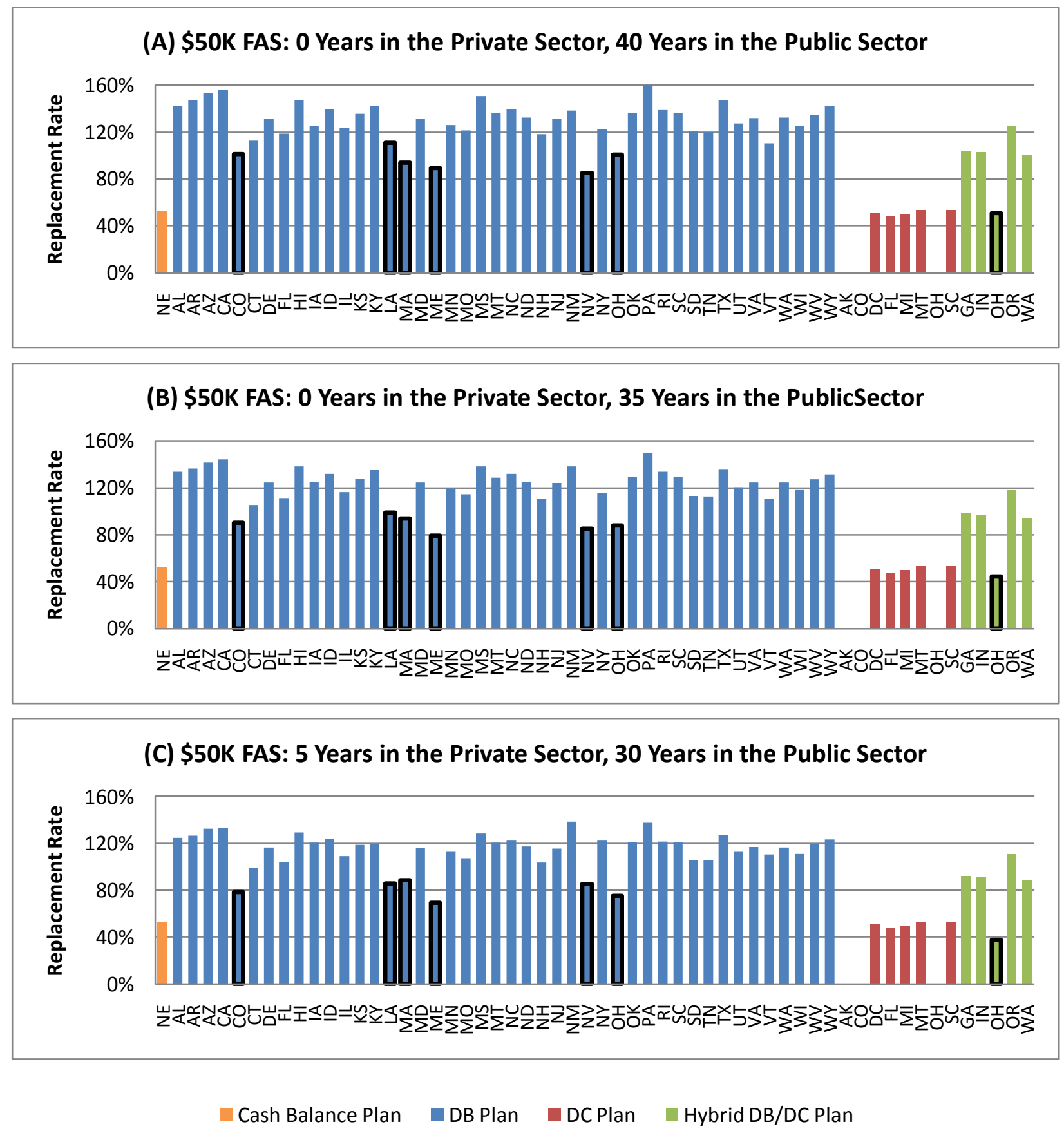

Note: States whose general public employees do not participate in Social Security have a black border. 
Appendix Figure A1 (cont'd). Joe the Bachelor's Retirement Income Replacement Rates under Various Scenarios

(Final Average Salary of \$50,000 Annually)
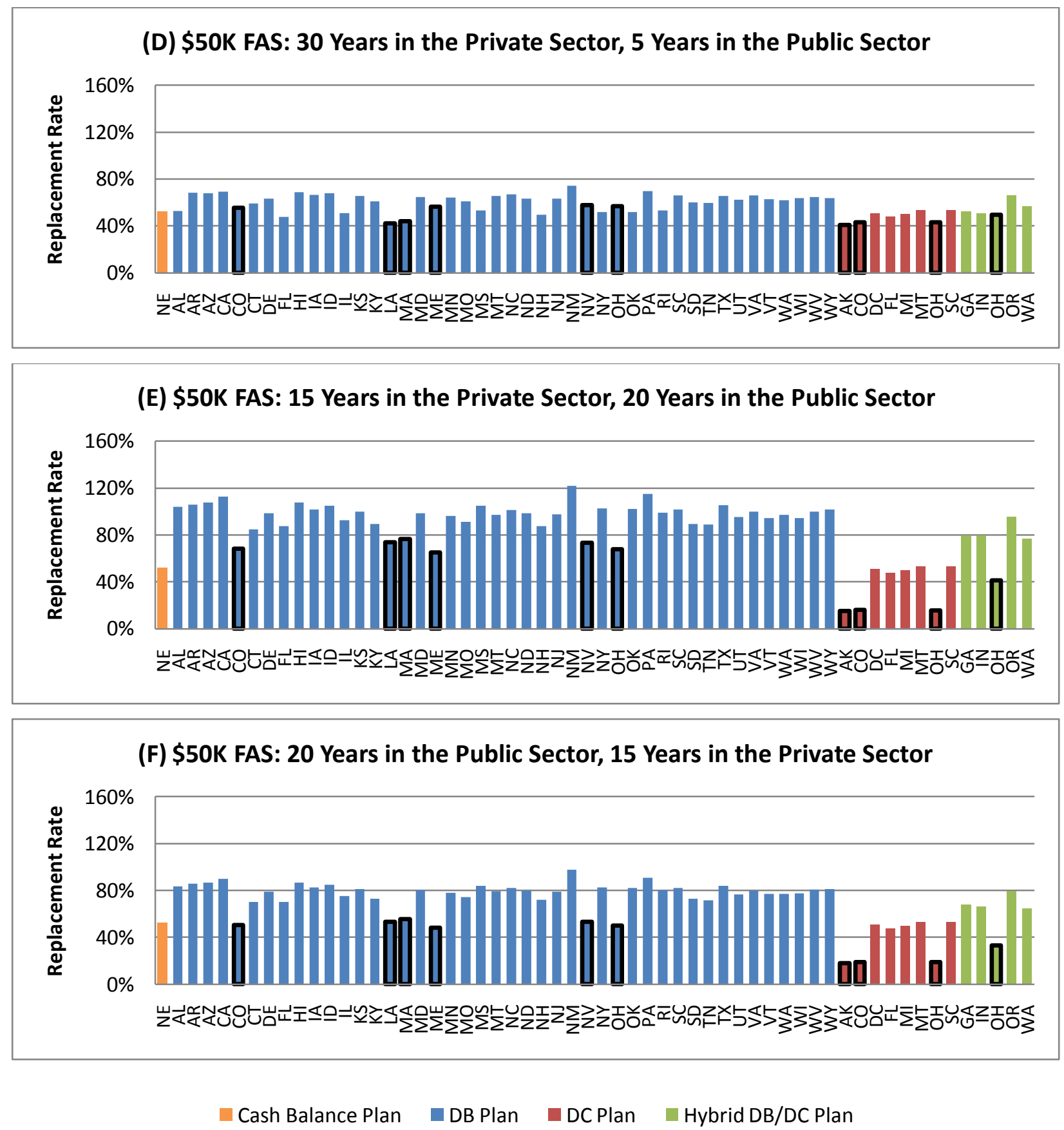

Note: States whose general public employees do not participate in Social Security have a black border. 
Appendix Figure A2. Joe the Bachelor's Retirement Income Replacement Rates under Various Scenarios

(Final Average Salary of \$100,000 Annually)
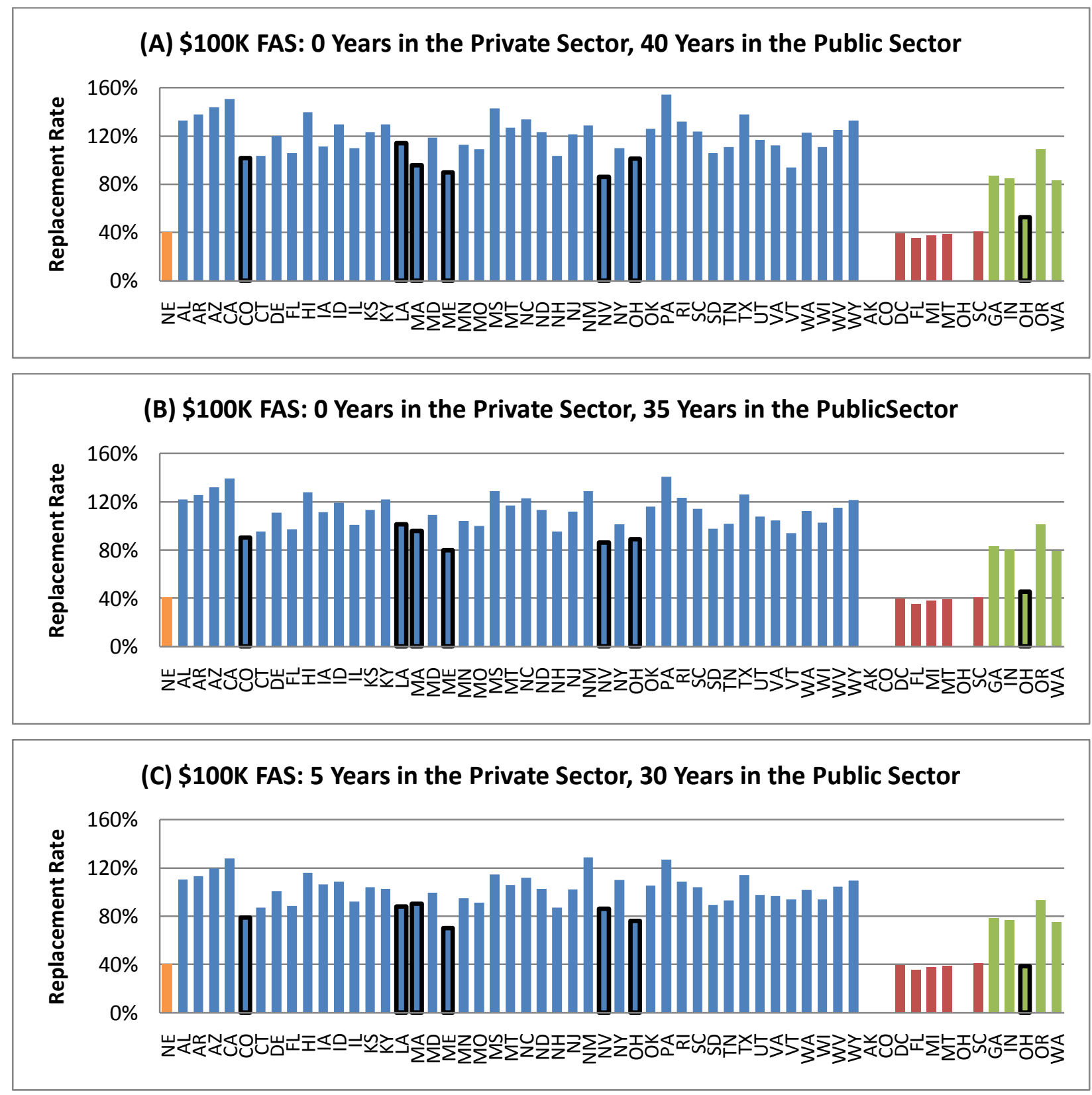

Cash Balance Plan DB Plan DCPlan Hybrid DB/DC Plan

Note: States whose general public employees do not participate in Social Security have a black border. 
Appendix Figure A2 (cont'd). Joe the Bachelor's Automatic Retirement Income Replacement Rates under Various Scenarios

(Final Average Salary of \$100,000 Annually)
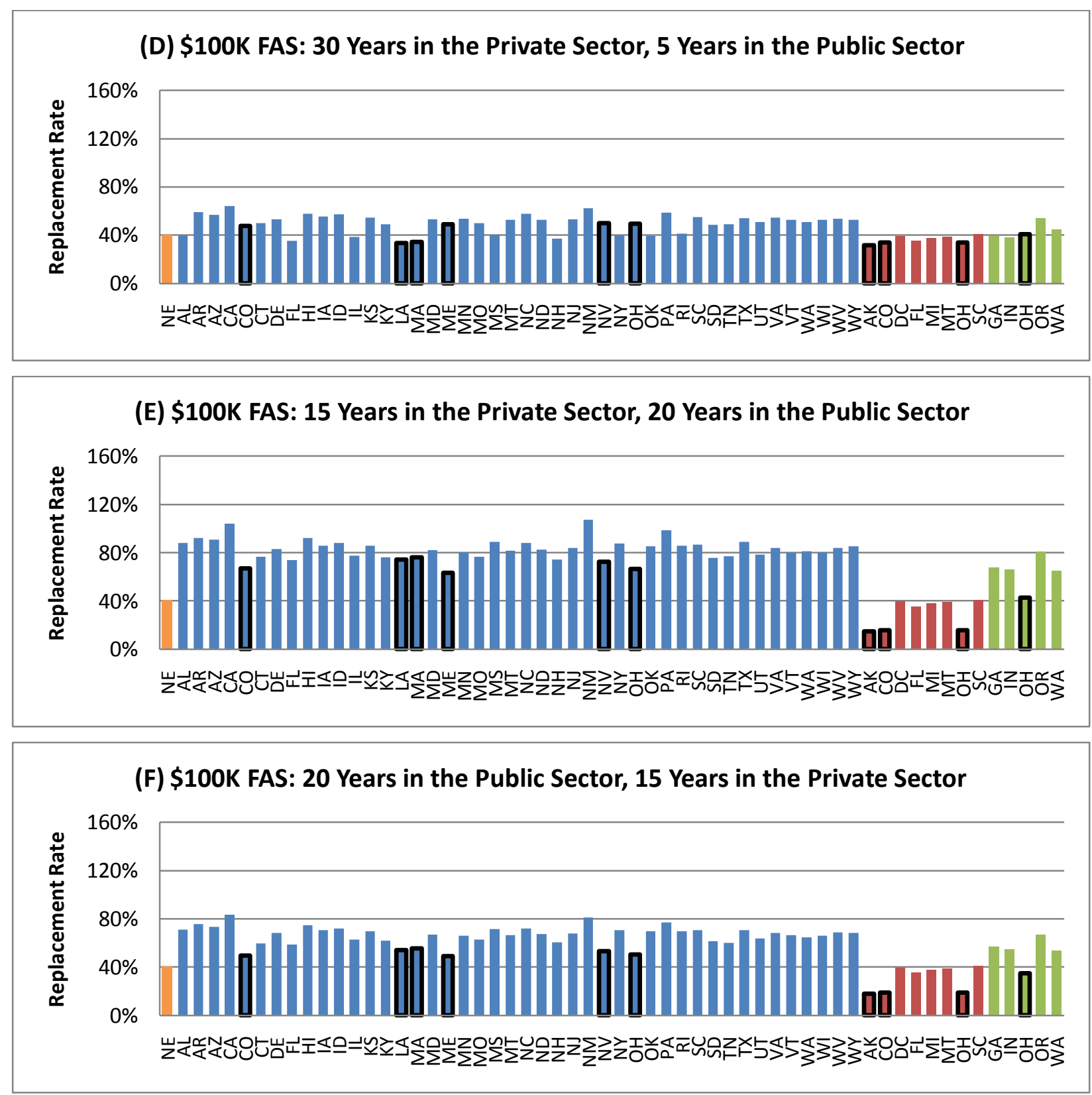

Cash Balance Plan DB Plan DC Plan Hybrid DB/DC Plan

Note: States whose general public employees do not participate in Social Security have a black border. 
Appendix Table B2. Joe the K-12 Teacher's Retirement Income Replacement Rates: Summary Statistics

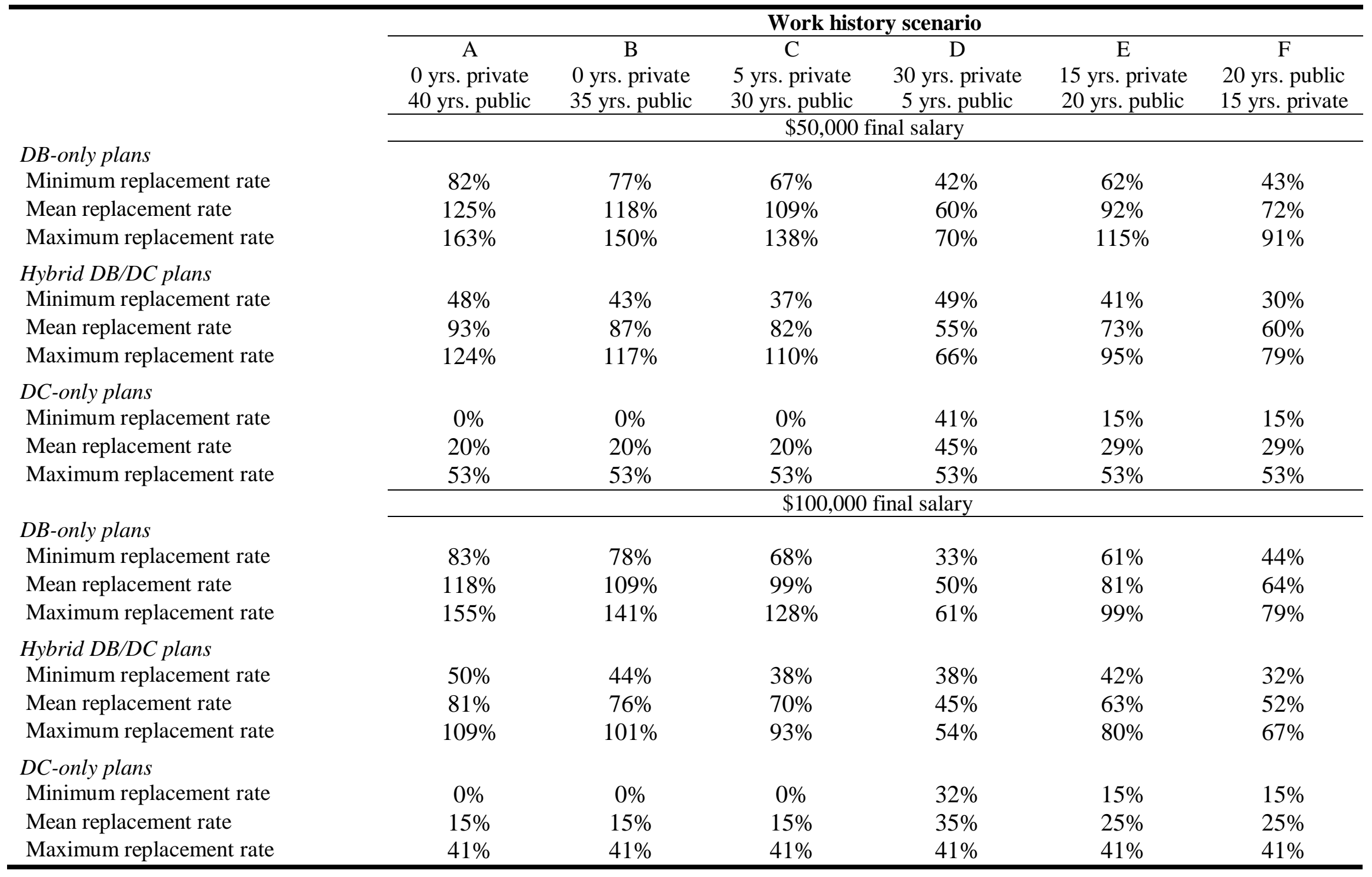


Appendix Figure B1. Joe the K-12 Teacher's Retirement Income Replacement Rates under Various Scenarios (Final Average Salary of \$50,000 Annually)
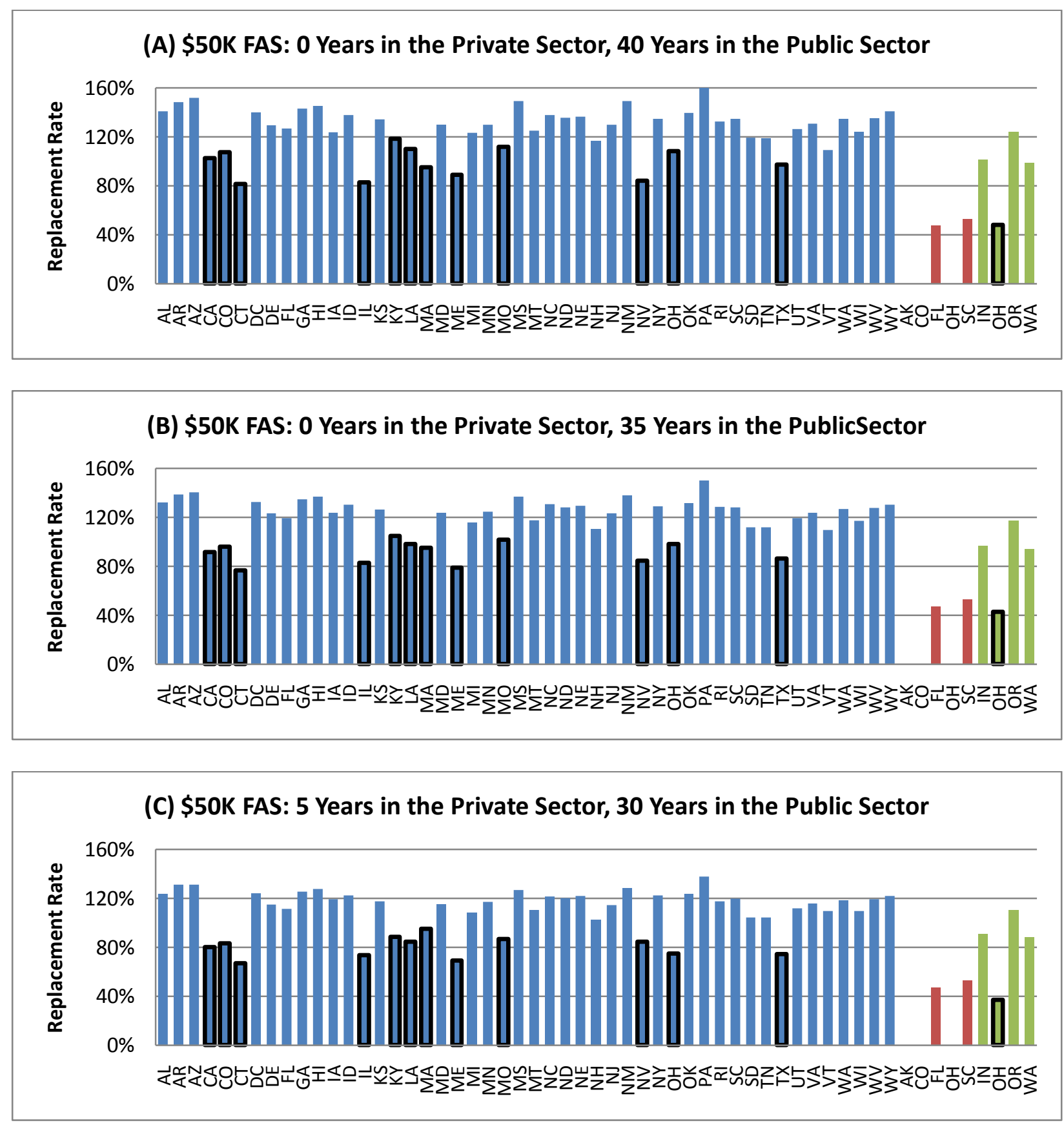

- Cash Balance Plan DB Plan DCPlan Hybrid DB/DC Plan

Note: States whose general public employees do not participate in Social Security have a black border. 
Appendix Figure B1 (cont'd). Joe the K-12 Teacher's Retirement Income Replacement Rates under Various Scenarios (Final Average Salary of \$50,000 Annually)
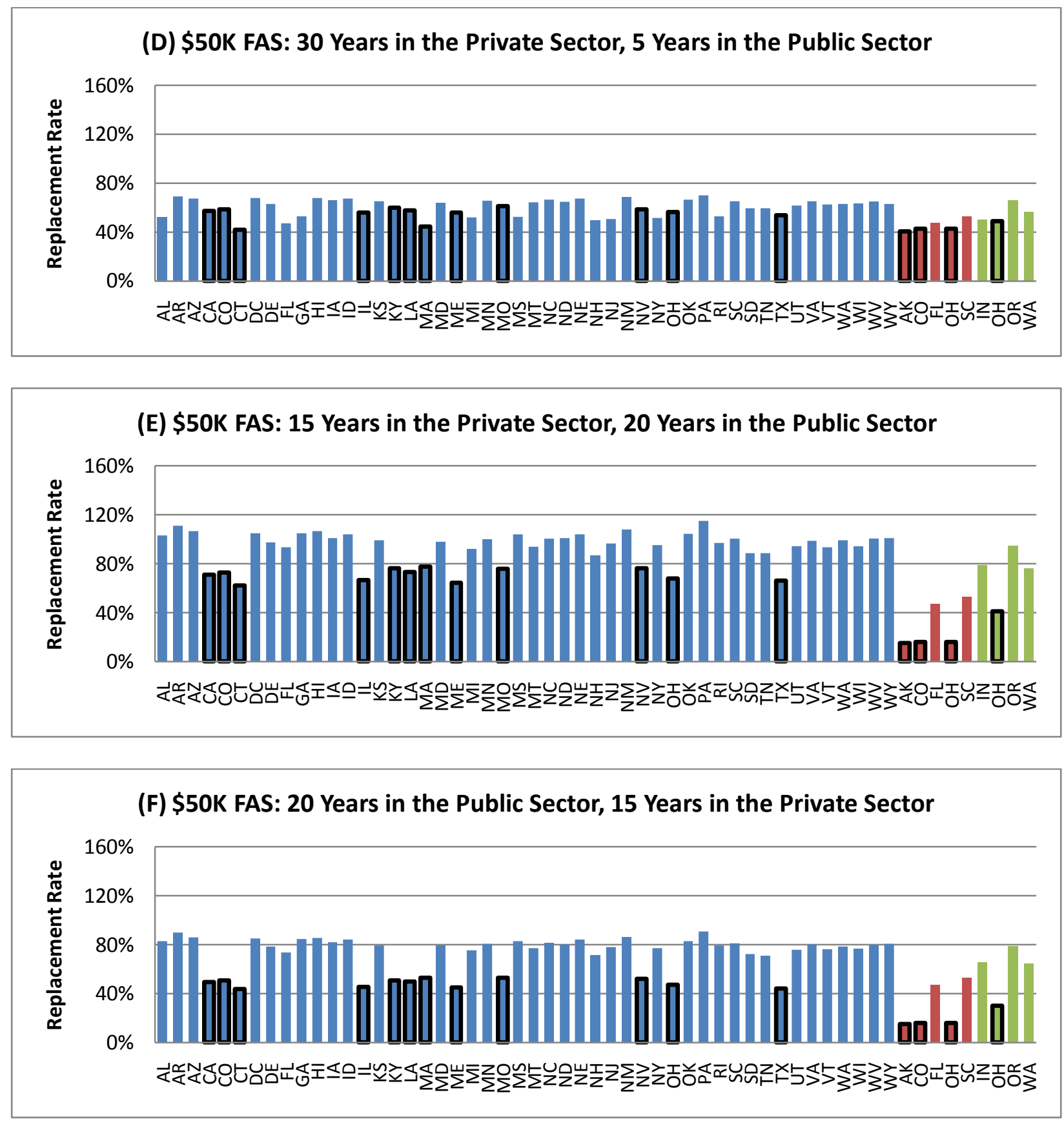

Cash Balance Plan $\quad$ DB Plan $\quad$ DC Plan $\quad$ Hybrid DB/DC Plan

Note: States whose general public employees do not participate in Social Security have a black border. 
Appendix Figure B2. Joe the K-12 Teacher's Retirement Income Replacement Rates under Various Scenarios

(Final Average Salary of \$100,000 Annually)
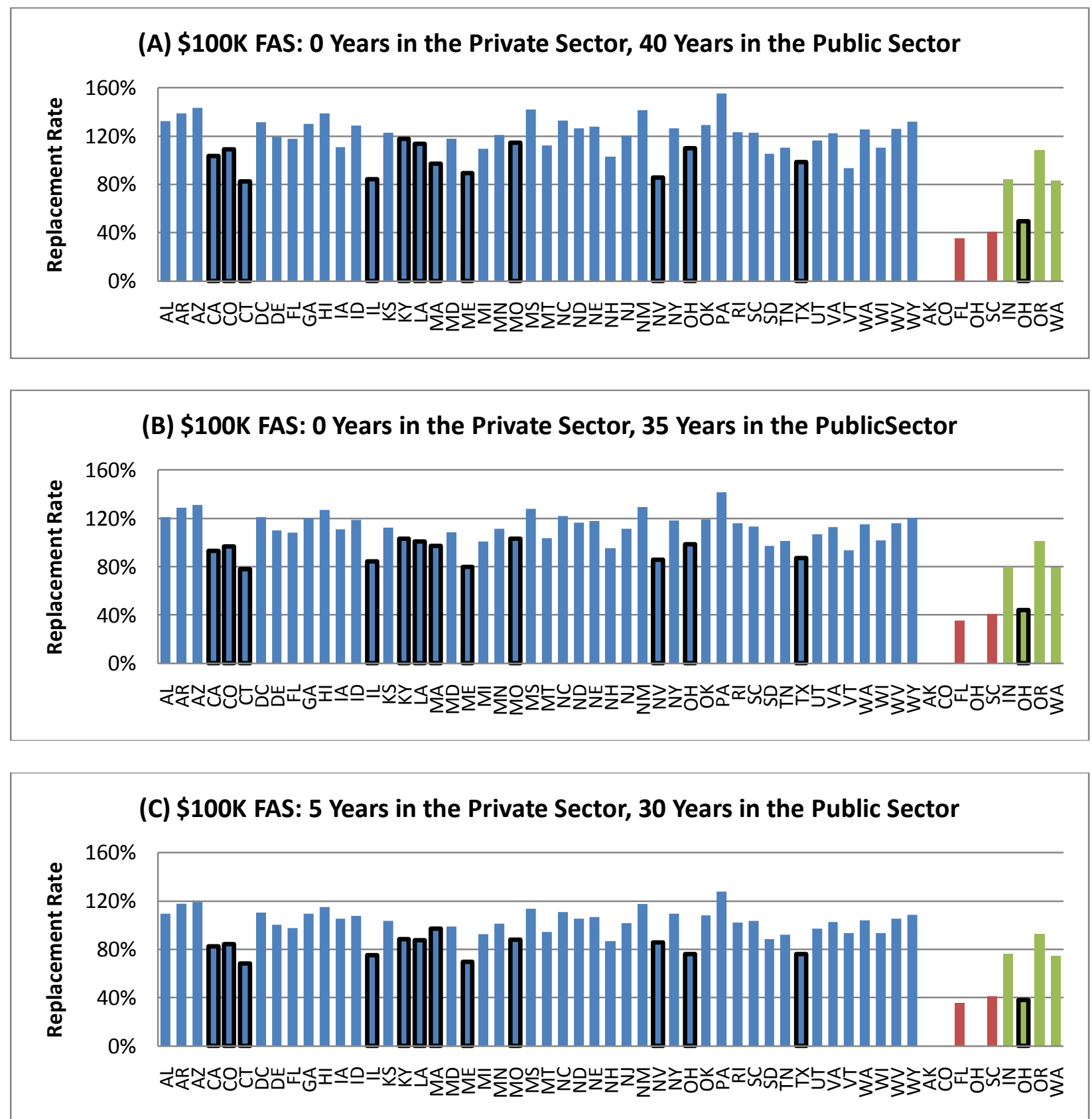

- Cash Balance Plan DB Plan DCPlan Hybrid DB/DC Plan

Note: States whose general public employees do not participate in Social Security have a black border. 
Appendix Figure B2 (cont'd). Joe the K-12 Teacher's Retirement Income Replacement Rates under Various Scenarios

(Final Average Salary of \$50,000 Annually)
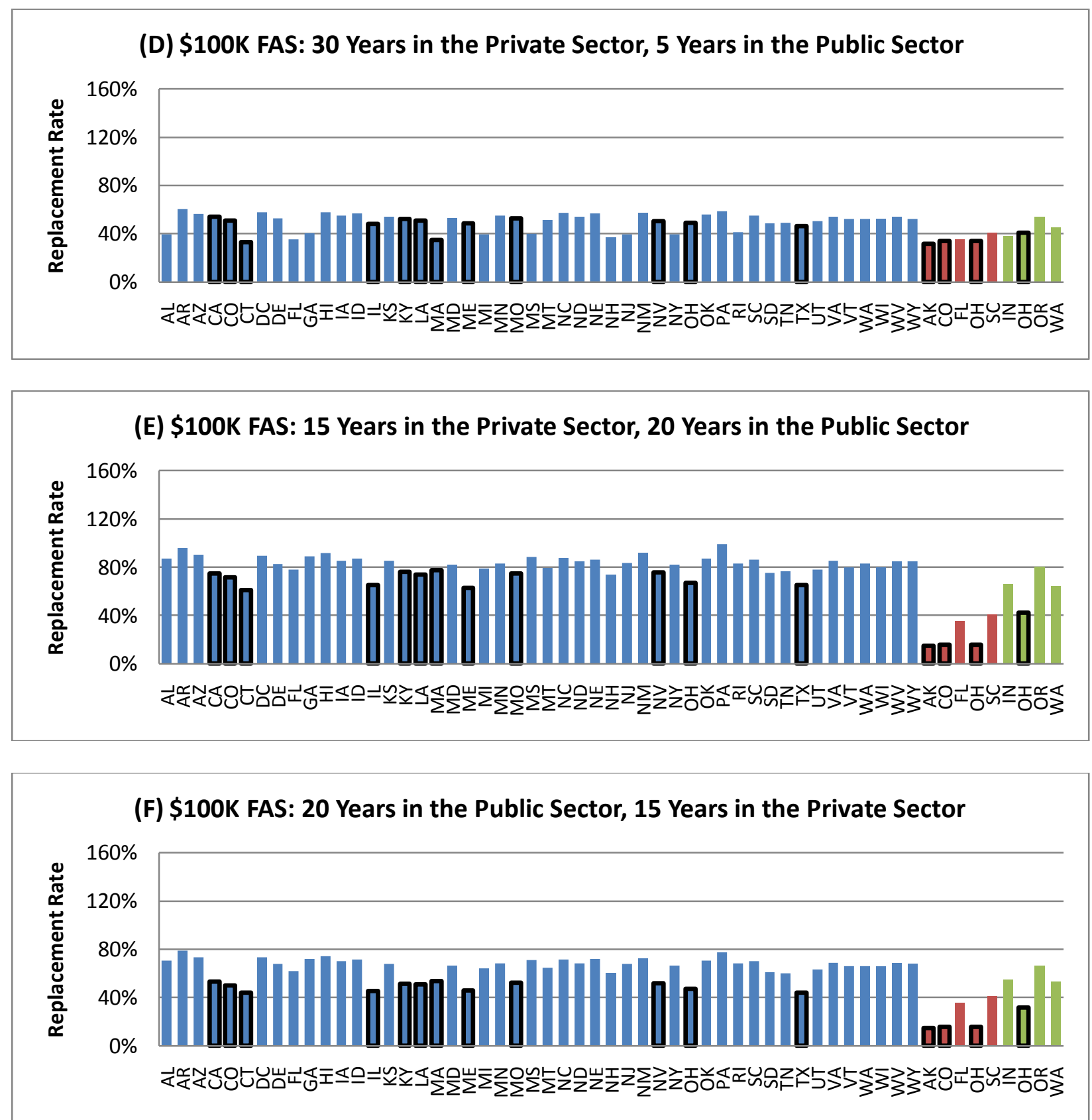

Cash Balance Plan $\square$ DB Plan DC Plan Hybrid DB/DC Plan

Note: States whose general public employees do not participate in Social Security have a black border. 